\title{
Investigating the Effect of Audit Committee Characteristics on Sustainability Reporting Level
}

\author{
Mostafa Abdi \\ Assistant Professor of Accounting, Roozbeh University, Zanjan, Iran. \\ abdi.accounting@roozbeh.ac.ir \\ Saeid Homayoun \\ Senior Lecturer in Accounting, Faculty of Education and Business, \\ University of Gavle, Sweden.(saeid.homayoun@hig.se) \\ Mahdi Kazemiolum* \\ Ph. D in Accounting, (Inviting), Faculty of Economic and Social Sciences, \\ Bu-Ali Sina University, Hamadan, Iran. \\ (Corresponding Author) \\ mkolum1361@gmail.com
}

\begin{abstract}
:
The purpose of this study is to investigate the effect of audit committee characteristics on the level of sustainability reporting of companies listed on the stock exchange with emphasis on agency theory, legitimacy theory and stakeholder theory. The data collection method is archival and to test the research hypotheses, the data of 152 companies listed on the stock exchange that were collected during the period 2014 to 2018 have been used. For data analysis, regression with a combined data approach was used. The Global Reporting Initiative's checklist has been used to measure sustainability reporting. The findings indicate that audit committee characteristics (size, independence, financial expertise and gender diversity of the members) have a positive and significant effect on corporate sustainability reporting level. Evidence suggests that the audit committee is effective as a corporate governance mechanism and control tool in improving the reporting quality in general and sustainability reporting in particular enhance to achieve the stakeholders goals. The findings of this study have important results for compilers of requirements and standards, management of companies and stakeholders. The findings of this study show the importance of disclosure requirements for non-financial information (environmental, governance and social information) for legislators and standardizers. The results of this study improve stakeholder awareness of the importance of corporate social responsibility, corporate governance, and environmental information on credit
\end{abstract}


Semiannually journal of Value \& Behavioral Accounting dof 10.29252/aapc.5.9.335

and investment decisions, and encourage companies to disclose sustainable reporting information in order to play their social role.

Keyword: Audit Committee, Corporate Governance, Stakeholders, Sustainability Reporting, Sustainable Development.

\section{Copyrights (c) (1)(2)}

This license only allowing others to download your works and share them with others as long as they credit you, but they can't change them in any way or use them commercial. 


\title{
مقاله يُؤوهشى
}

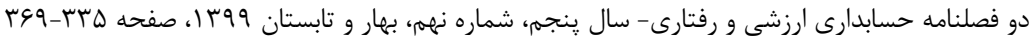

\section{بررسى تاثير ويزَىهاى كميتهاى حسابرسى بر سطح كَارشكَى

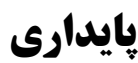

\author{
مصطفى عبدى' سعيد همايون' مهدى كاظمى علوم"r

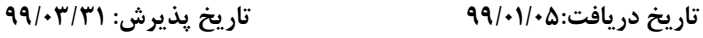

\begin{abstract}
جكيده
هدف اين يزوهش بررسى تاثير ويزگى هاى كميته حسابرسى بر سطح گزارشكَى بايدارى

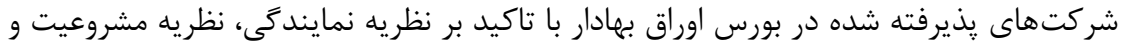

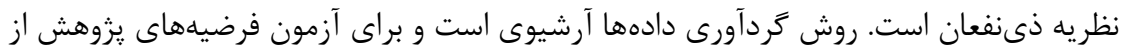

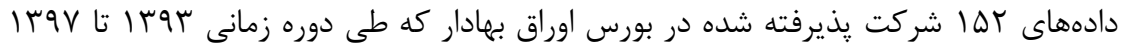

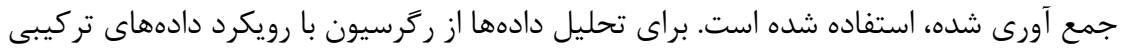

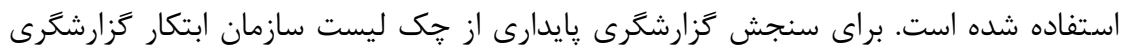
جهانى استفاده شده است. يافتهها حاكى از آن است كه ويزّى هائ كميته حسابرسى (اندازئ، استقلال، تخصص مالى و تنوع جنسيتى اعضاى كميته حسابرسى) تاثير مثبت و معنادارى بر انداني

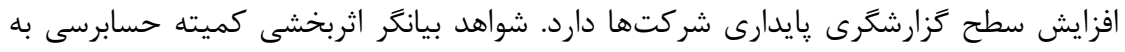

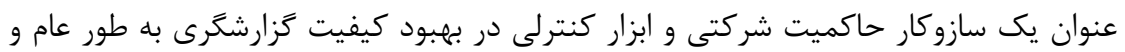

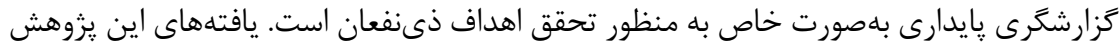

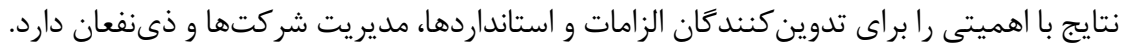

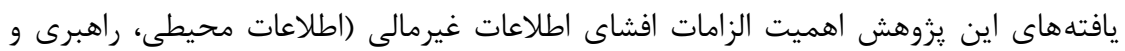

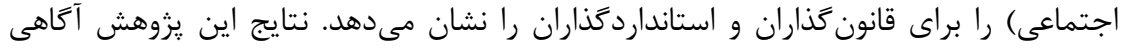

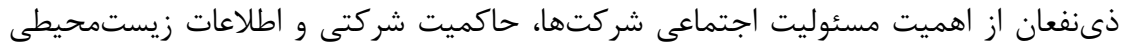

\footnotetext{
'استاديار حسابدارى، موسسه آموزش عالى غيرانتفاعى روزبه، زنجان، ايران. abdi.accounting@roozbeh.ac.ir

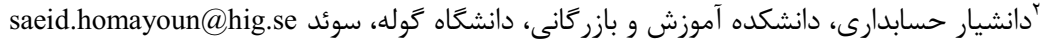

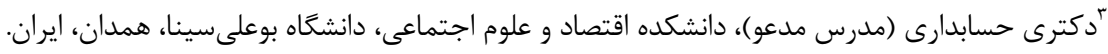
Mkolum1361@gmail.com (نويسنده مسئول)
} 
دو فصلنامه حسابدارى ارزشى و رفتارى، سال ينجم، شماره نهه، بهار و تابستان 99س1

דוז

درباره تصميمات اعتبارى و سرمايه كذارى را بهبود بخشيده و شركتها را ترغيب مىنمايد تا

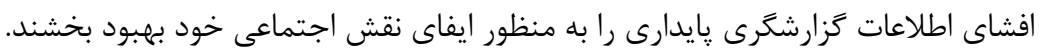

وازَّان كليدى: توسعه يايدار، حاكميت شركتى، ذىنفعان، كميته حسابرسى، كزارشكَى

קإيدارى 


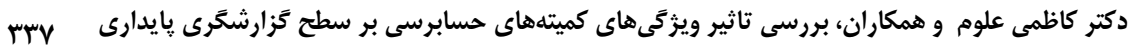

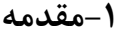

كزارشكرى پايدارى كزارشى سازمانى است كه اطلاعاتى بِيرامون عملكرد اقتصادى، زيست

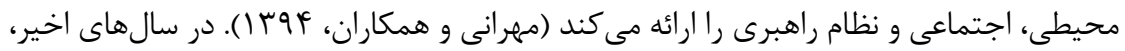
كزارشكرى پايدارى' به بخش مركزى راهبردهاى تجارى وارد شده است و يزوهشكَران، بايدارى

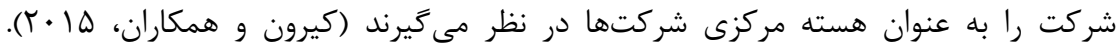

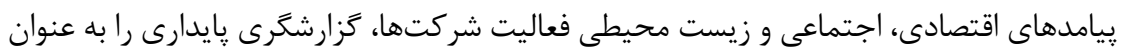
يكى از موضوعات خالش برانكيز تحقيقات حسابدارى مطرح ساخته است (كاشانى يور و همكاران،

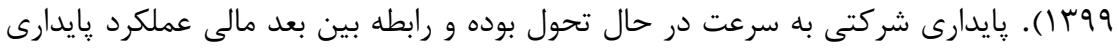

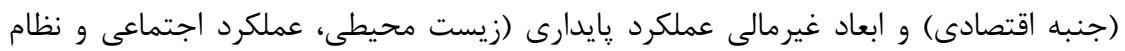

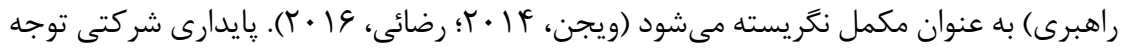

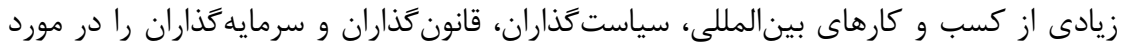

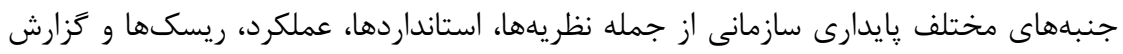

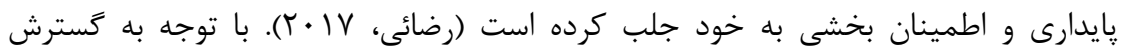
فعاليتهاى تجارى در جهان و اهميت پايدارى در حوزههاى سازمانى، دانشآهى و حرفهاى، مقوله

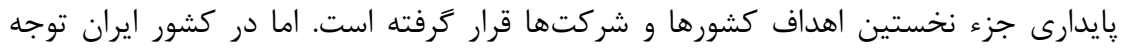

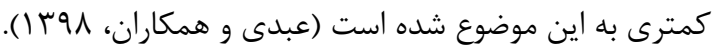

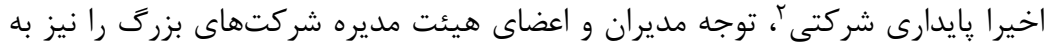

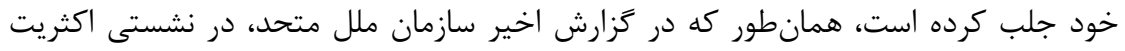

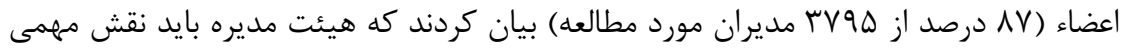

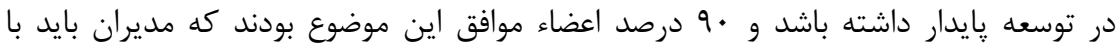

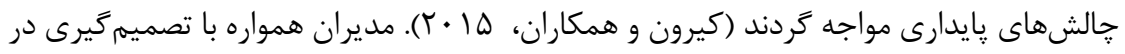

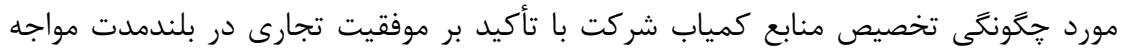
هستند (وادوك و كريز، لو9 (1)). نهادهاى حاكميت در انواع سازمان ها مانند هيئت مديره، كميته حسابرسى و حسابرسان داخلى و كميته ريسك براى استفاده مسئولانه از منابع خود و به منانه منظور

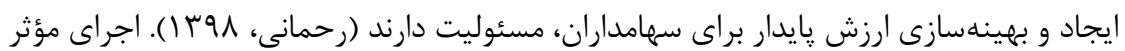
الزامات حاكميت شركتى، عامل اصلى موفقيت در كسب و كار تجارى در بلندمدت است. بارئ رويدهاى

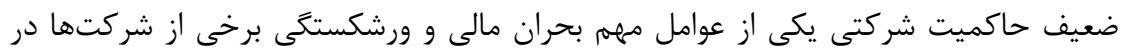

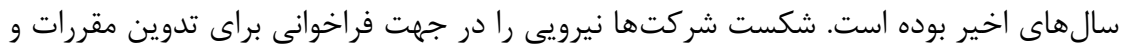

${ }^{1}$ Sustainability Reporting

${ }^{2}$ Corporate Sustainability 
الزامات سختتر، رويههاى قوىتر حاكميت شركتى و افشاى شفافتر اطلاعات مالى و غيرمالى

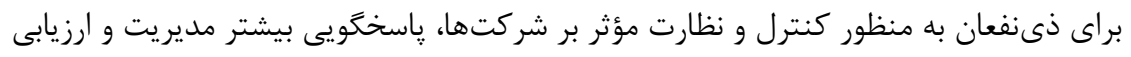

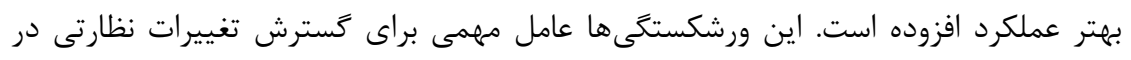

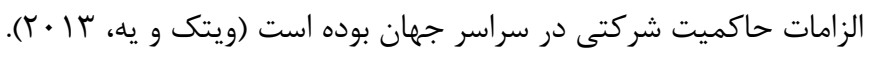

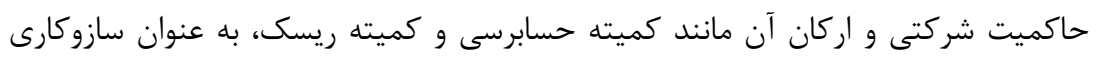

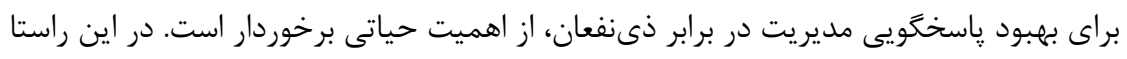

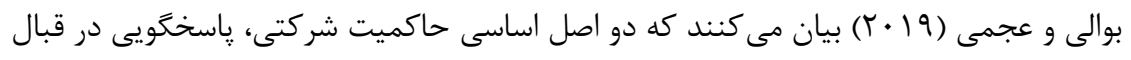

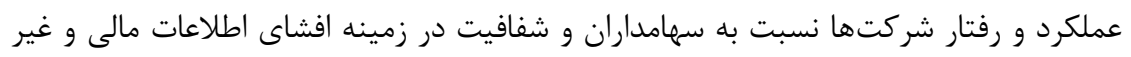

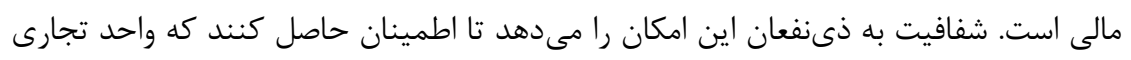

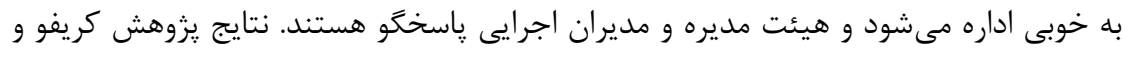

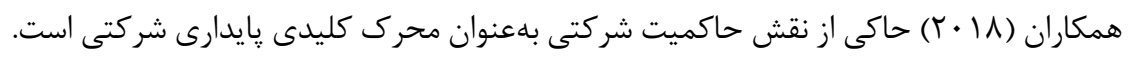

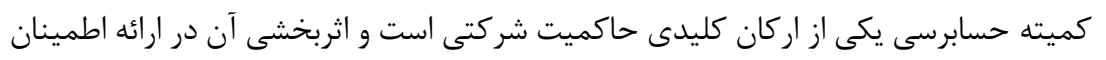

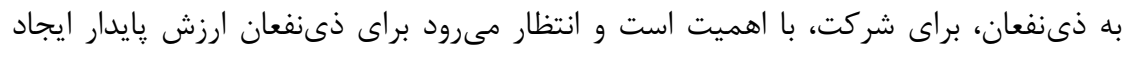

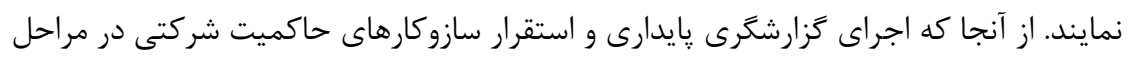

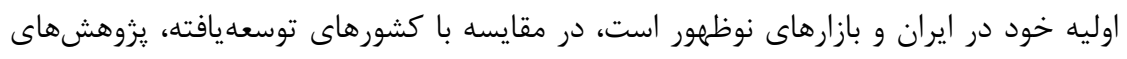

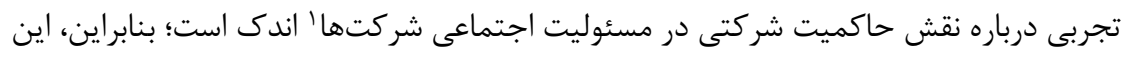

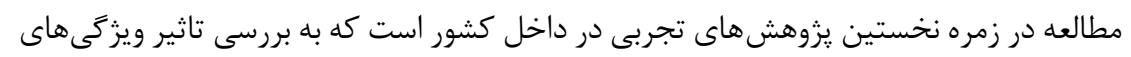

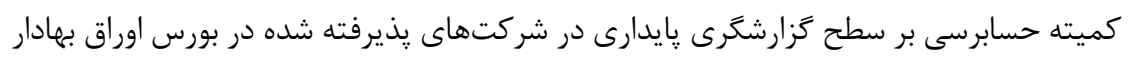

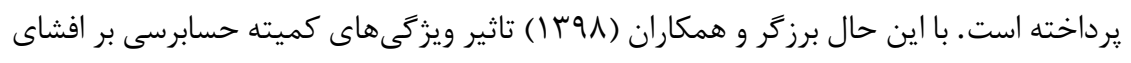

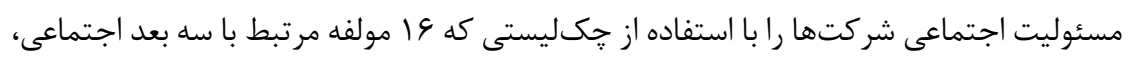

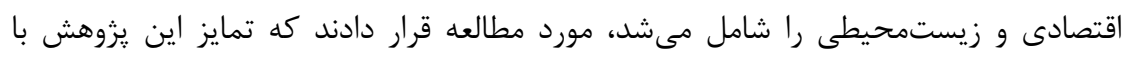

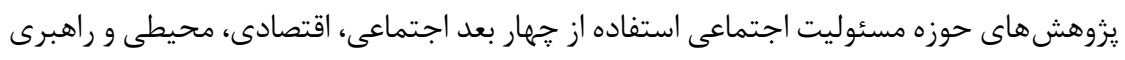

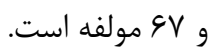

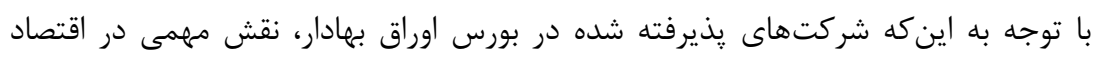

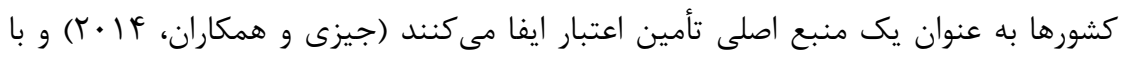

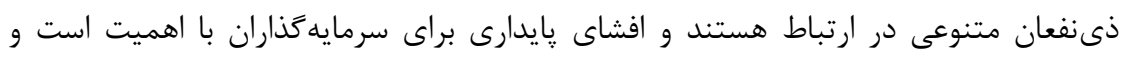

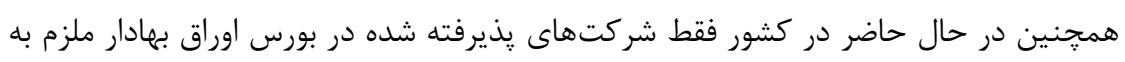

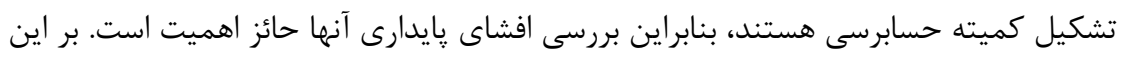

\section{${ }^{1} \mathrm{CSR}$}




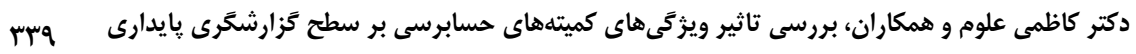

اساس، عوامل مؤثر بر افشاى اطلاعات بايدارى بايد مورد تأكيد قرار كَيرند. اين مطالعه از ابعاد

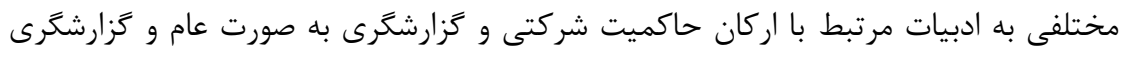

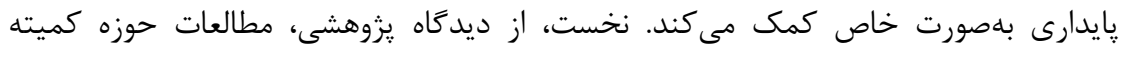

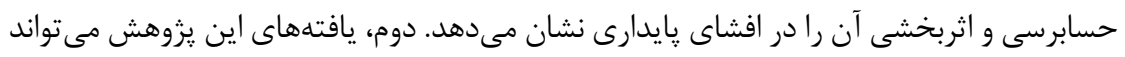

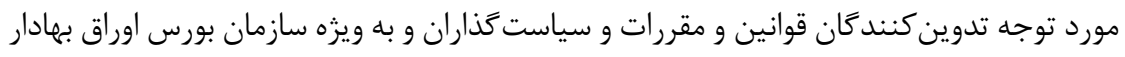

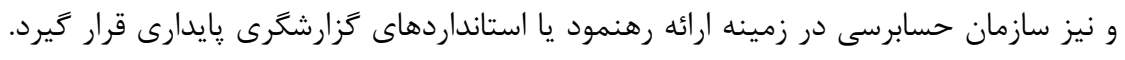

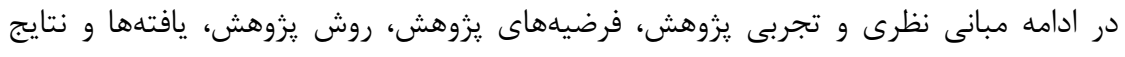
يزوهش ارائه مىشود.

\section{r-مبانى نظرى و وِيشينه يزوهش " كزارشكرى يايدارى}

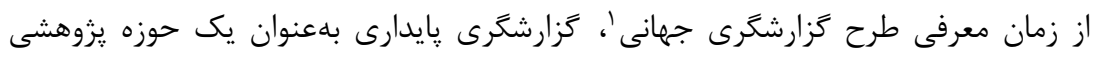

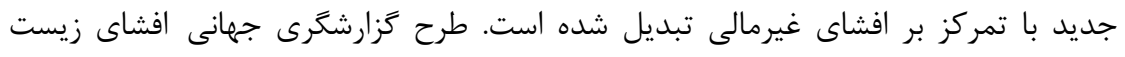

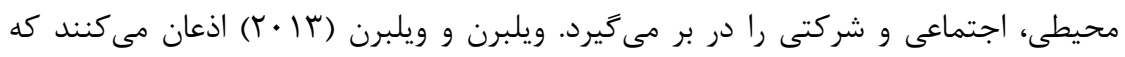

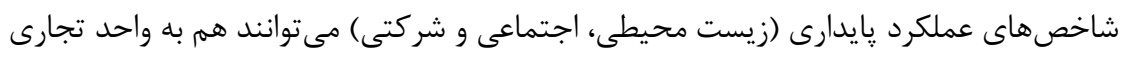

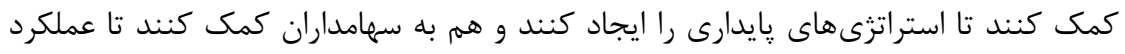

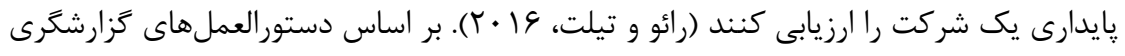

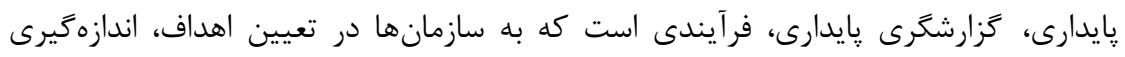

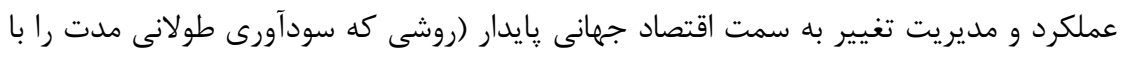

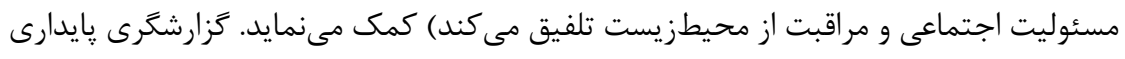

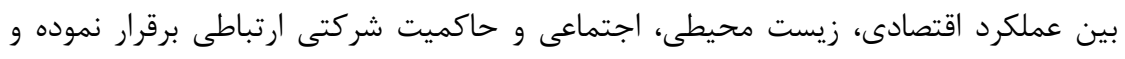

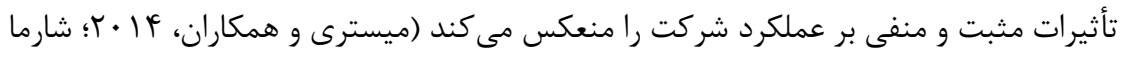

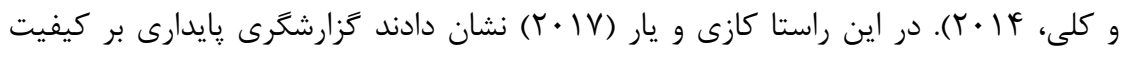

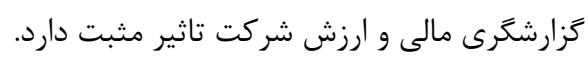

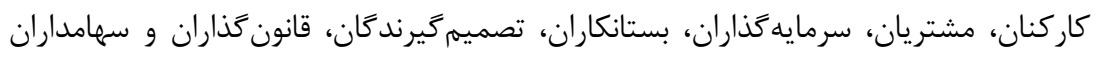

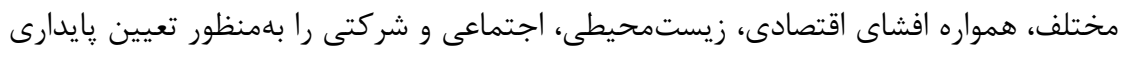

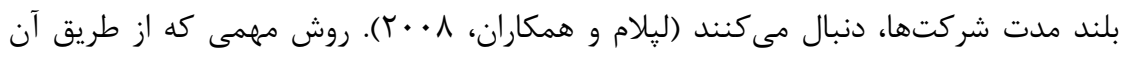

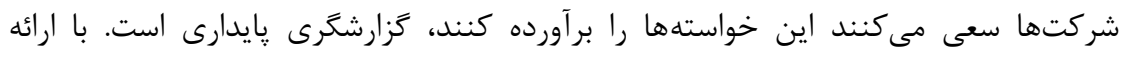

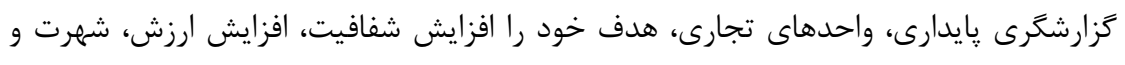

${ }^{1}$ Global Reporting Initiative 
مشروعيت، دستيابى به رقابت و ايجاد انحيزه در كاركنان مى دانند (هرزيخ و همكاران، و • •؟).

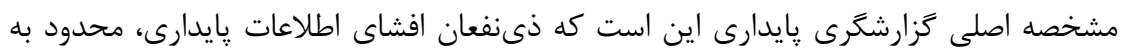

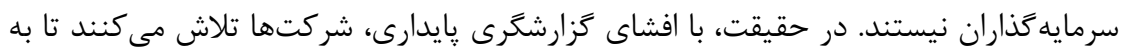

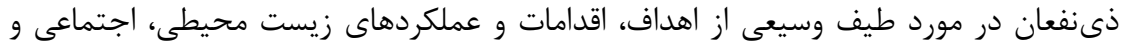

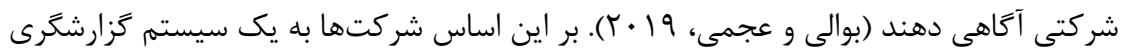

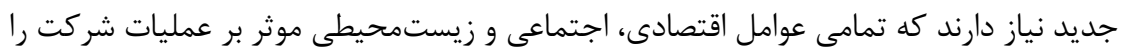

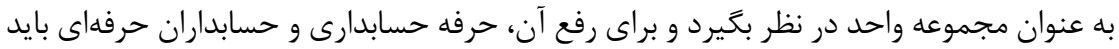

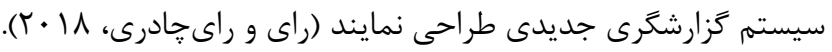

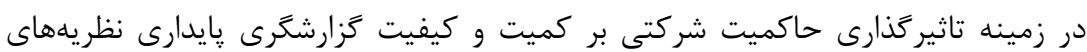

متفاوتى وجود دارد كه در ادامه به مههمترين نظريههاى موجود در اين زمينه اشاره مئى بردرد.

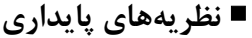

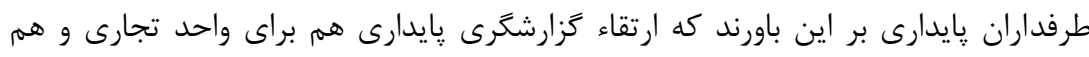

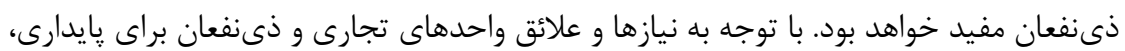

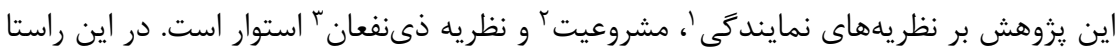

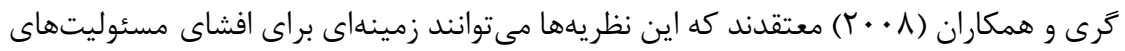
اجتماعى و افشاى زيست محيطى، اجتماعى و شركتى فراهم آورند.

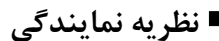

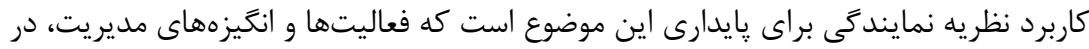

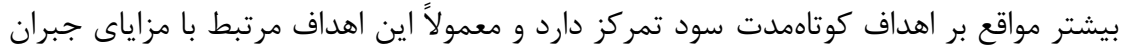

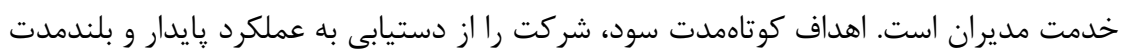
براى ذىنفعان باز مىدارد. در اين نظريه فعاليتهاى ابعاد غيرمالى پايدارى (زيست محيطى،

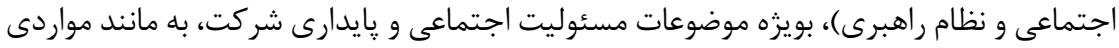

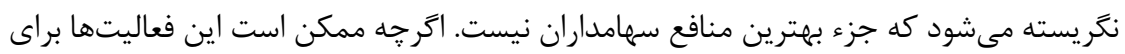

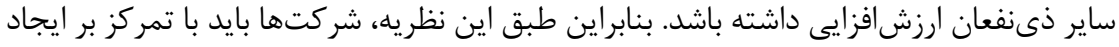

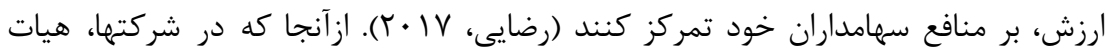
مديره بالاترين مقام اجرايى در رابطه با تنظيم سياستهاى شركت و تصميمات مهرم در زمينه

\footnotetext{
${ }^{1}$ Agency Theory

${ }^{2}$ Legitimacy Theory

${ }^{3}$ Stakeholder Theory
} 


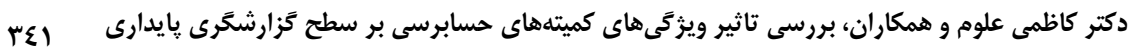

استراتزىهاى شركت است، نقش مهمى در تصميمَّيرى و تعيين استراتزيهاى كزارش پايدارى

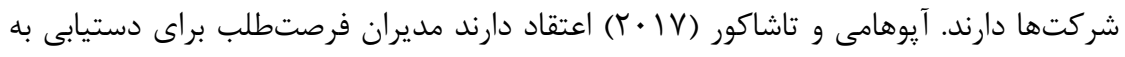

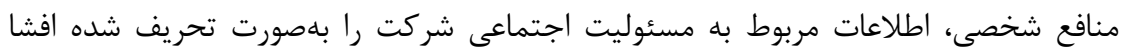

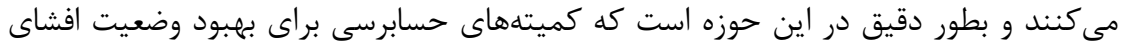

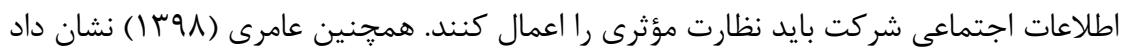

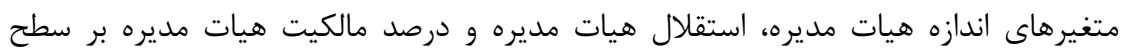

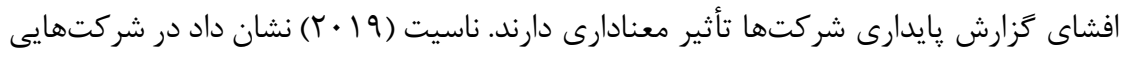

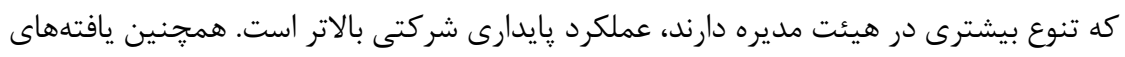

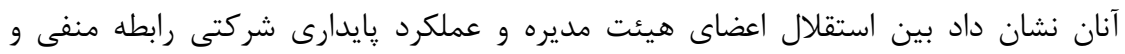

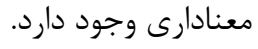

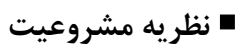

نظريه مشروعيت كه مبتنى بر ديدگاه سياسى_اجتماعى ايجاد شده، به اين موضوع اشاره دارد

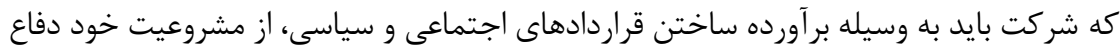

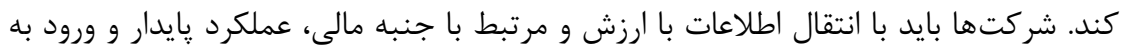

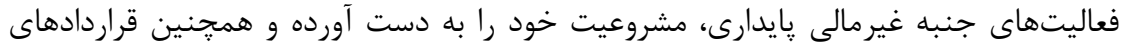

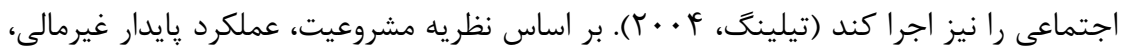

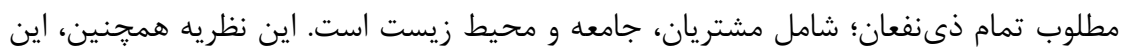

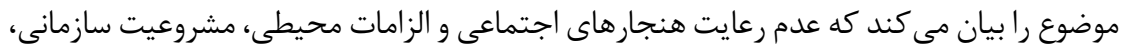

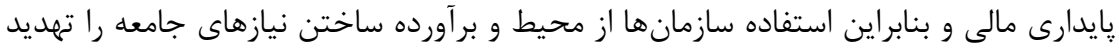

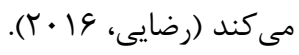

بر اساس نظريه مشروعيت، افشاى اطلاعات در كزارشهاى سالانه و ساير روشها باريها به منظور

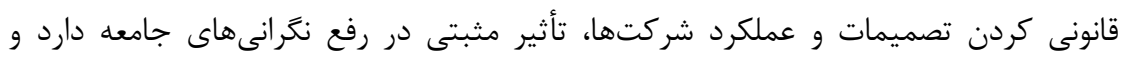

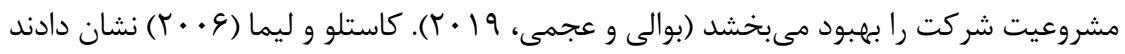

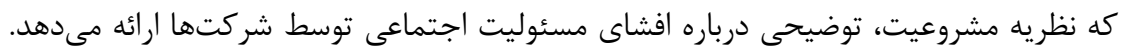

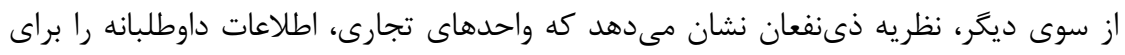

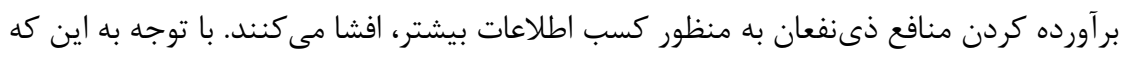

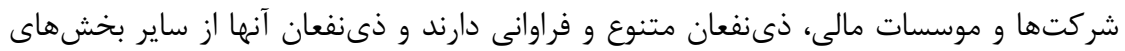

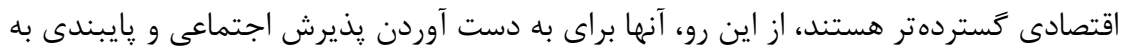


قراردادهاى اجتماعى با جامعه و نيز براى تحقق انتظارات ذىنفعان خود، تحت فشار بسيار زيادى

هستند.

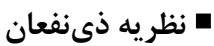

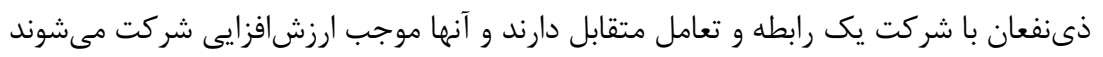

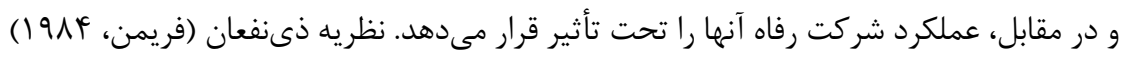

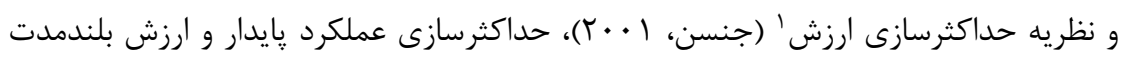

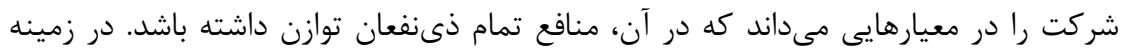

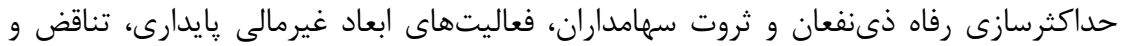

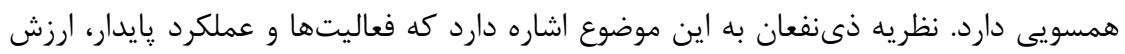

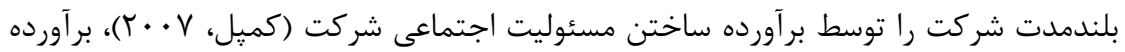

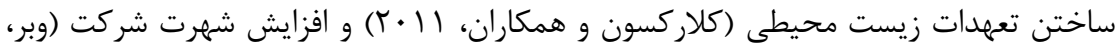

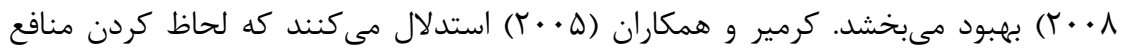

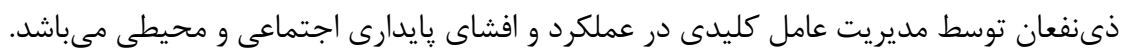

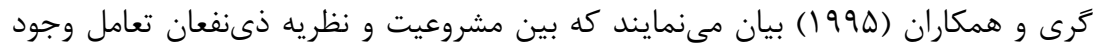

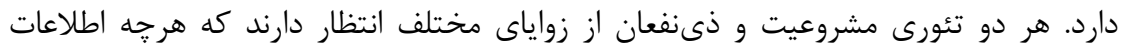

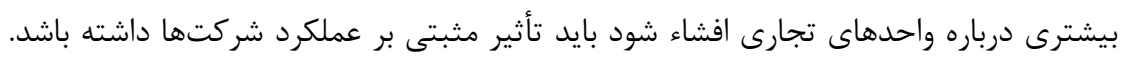
افشاى بيشتر منجر به كاهش اهميت مشكل عدم تقارن اطلاعاتى (كلار كسون و همكاران، 1 • • T)،

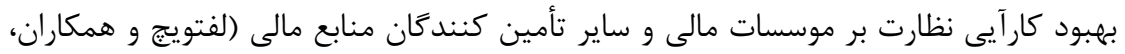

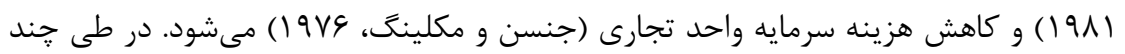

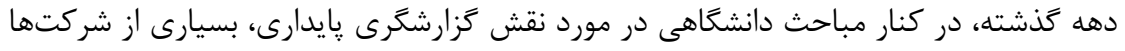

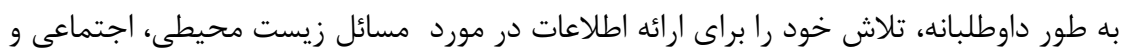

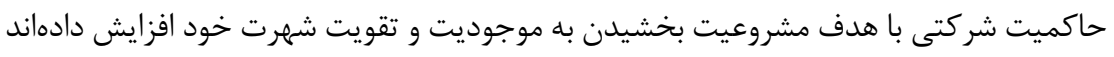

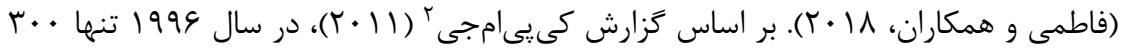

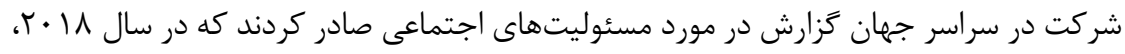

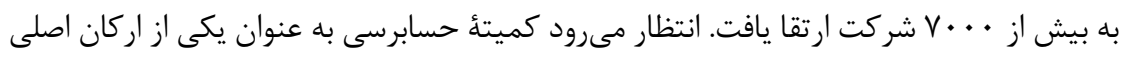

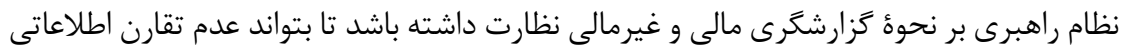

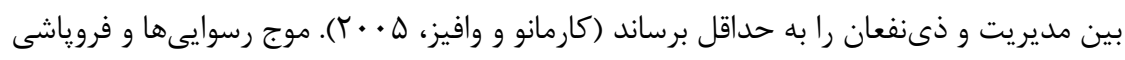

${ }^{1}$ Value Maximization Theory

${ }^{2} \mathrm{KPMG}$ 
دكتر كاظمى علوم و همكاران، بررسى تاثير ويثَّىهاى كميتههاى حسابرسى بر سطح كزارشكَى يايدارى سعب

شركتها و مؤسسههاى مالى بزرى دنيا، سبب شـده اسـت قـوانين جديـدى در سـاختار

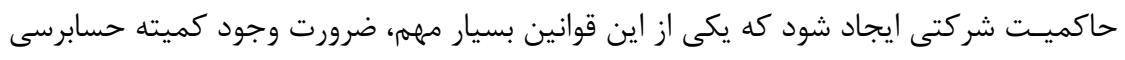

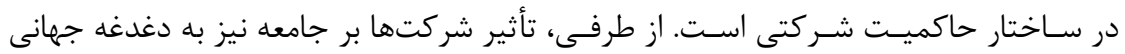

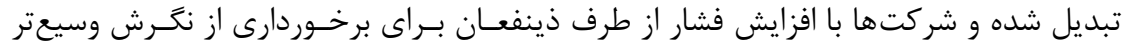

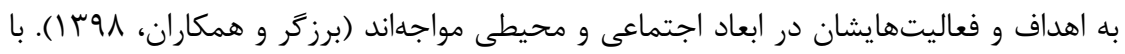

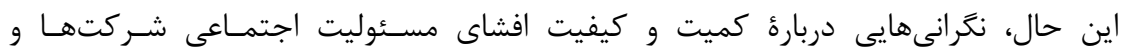

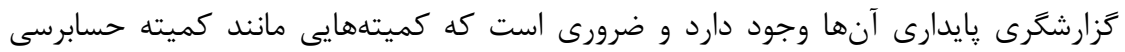

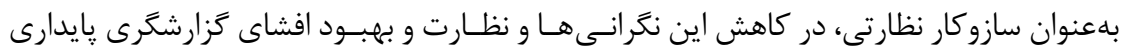

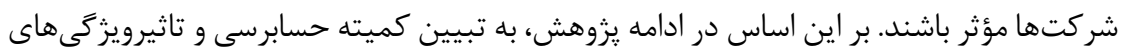

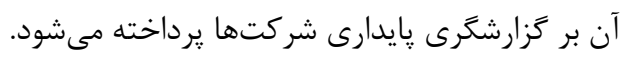

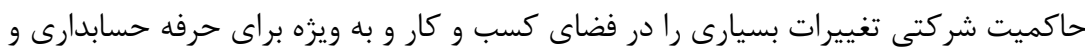

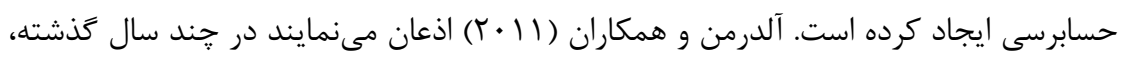
تمركز زيادى بر نقش كميتههاى حسابرسى وجود داشته است، زيرا آنها به عنوان إنهان سازوكار

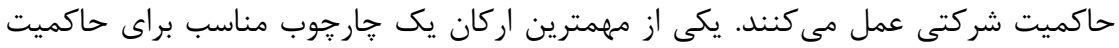

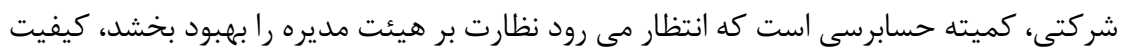

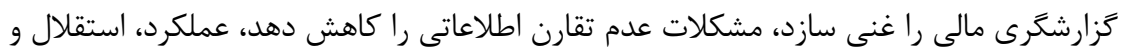

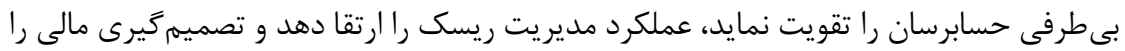

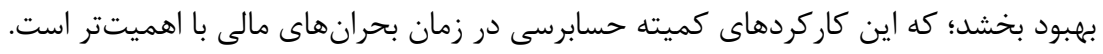

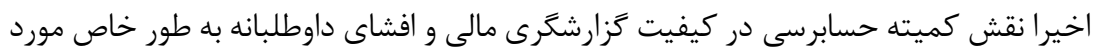

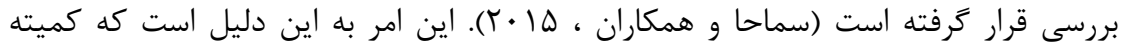

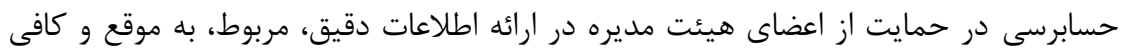

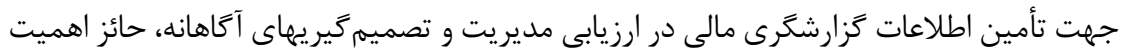

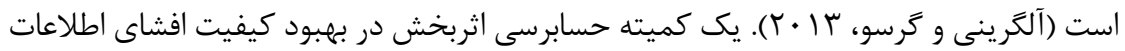

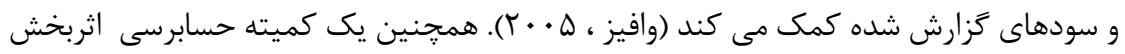

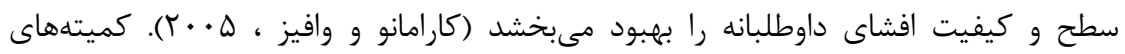
حسابرسى با بررسى نقاط ضعف كنترلهاى داخلى بر بهبود كيفيت كزارشكرى مالى كمك

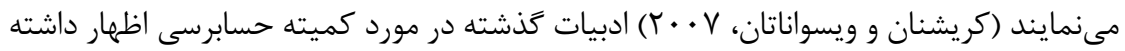

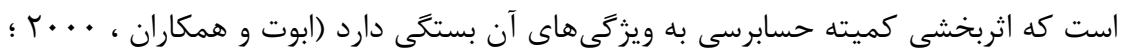




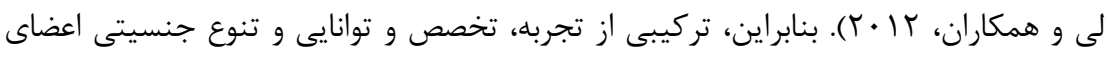

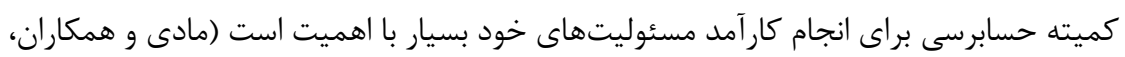

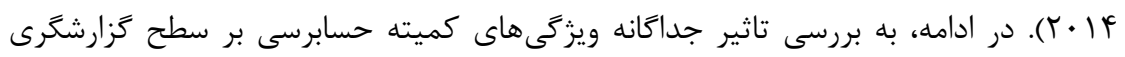

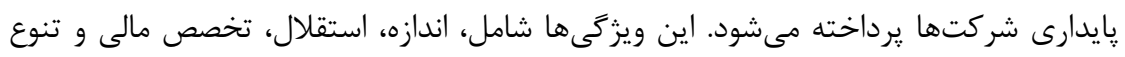

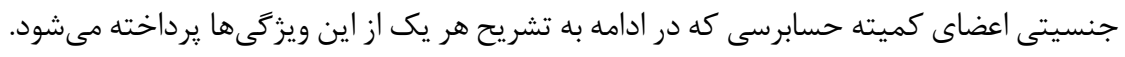

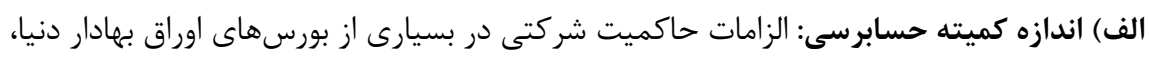

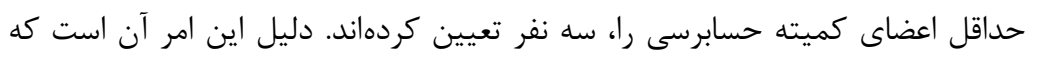

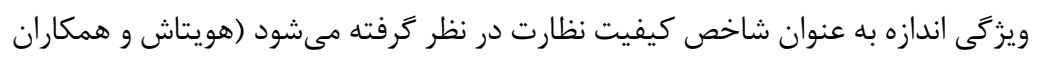

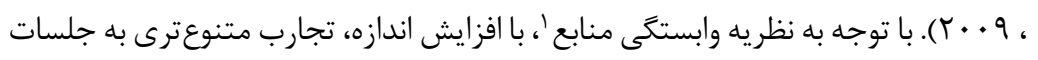

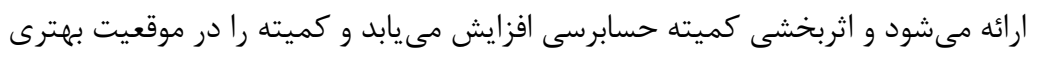

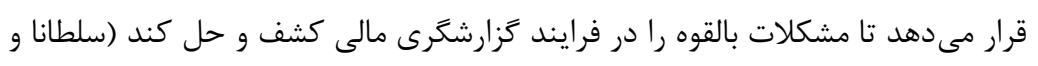

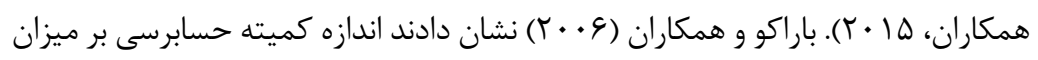

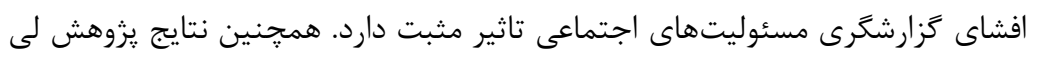

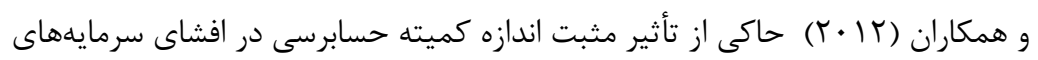

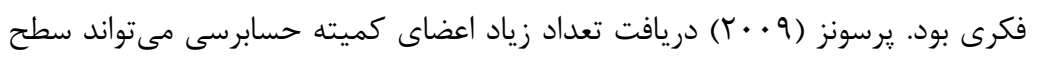

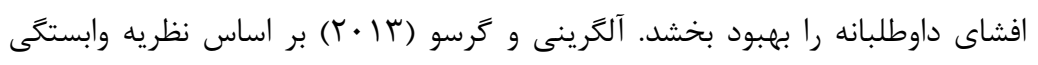

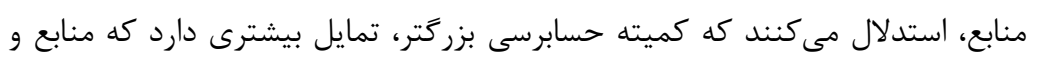

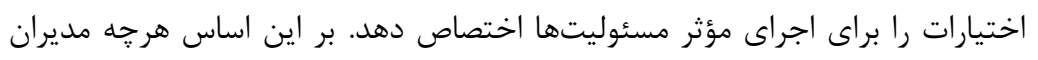

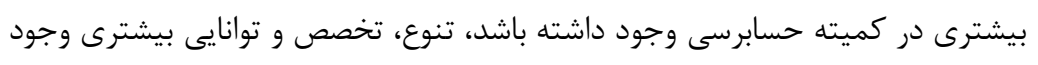

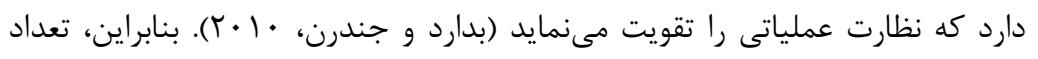

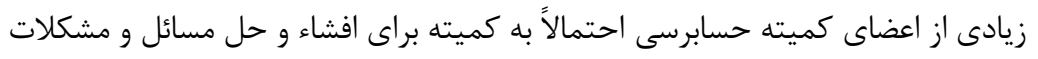

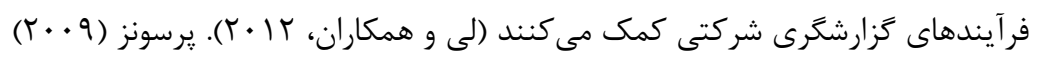

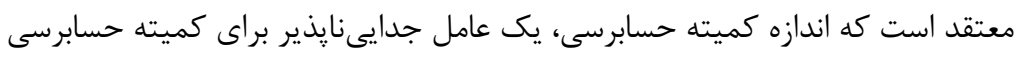

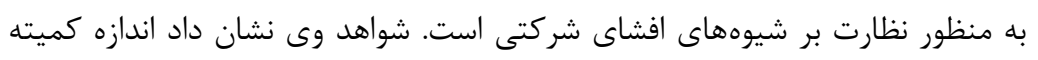

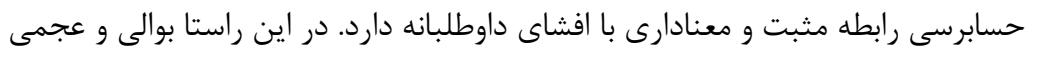

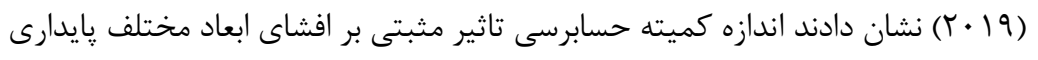

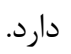

\footnotetext{
${ }^{1}$ Resource Dependence Theory (RTD)
} 
ب) استقلال اعضاى كميته حسابرسى: نقش مديران مستقل در دستيابى به اهداف هيئت مديره

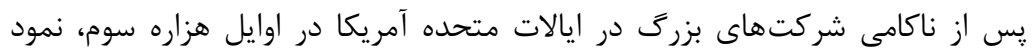

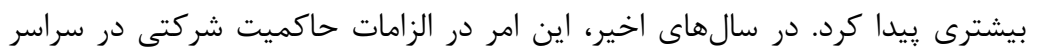

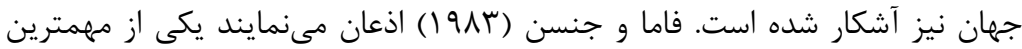
اهداف براى حضور اين مديران، حمايت از منافع سهامداران است. به كَفته حنيفا و كوكى

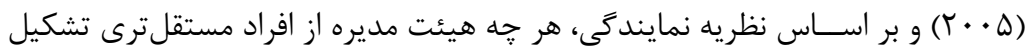

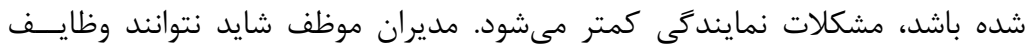

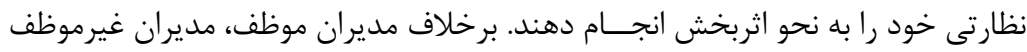

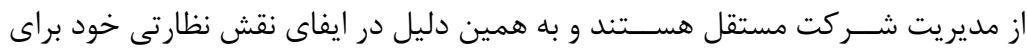

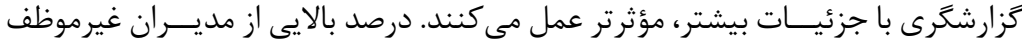

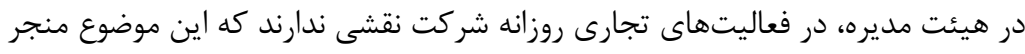

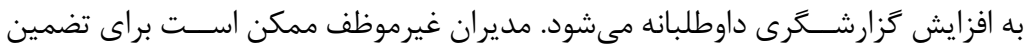
تجانس بين فعاليتهاى سازمان و ارزشهاى اجتماعى يا كسب مارئ مشروعيت سازمانى

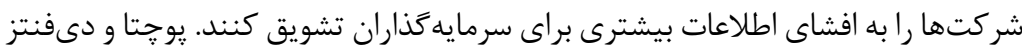

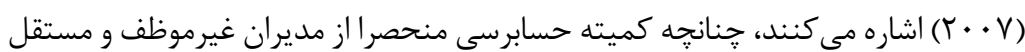

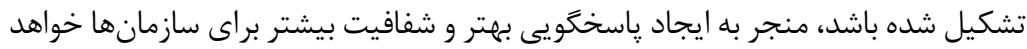

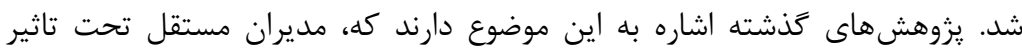

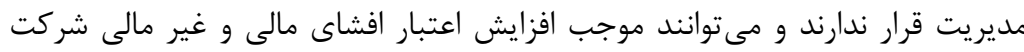

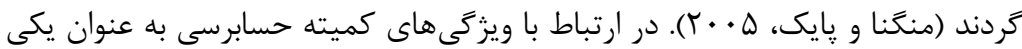

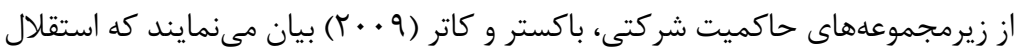

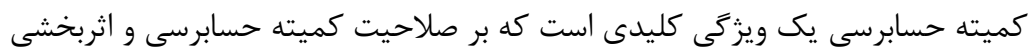

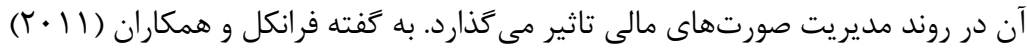

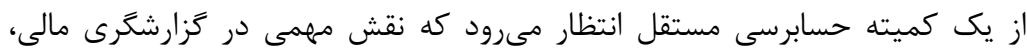

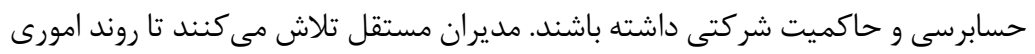

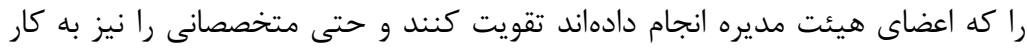
كيرند تا از تخصص و دانش آنها استفاده كنند و موجب تداوم فعاليت واحد تجارى كرئ كردند.

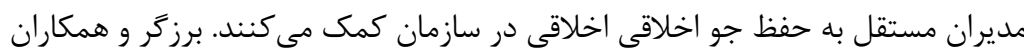

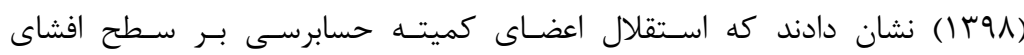

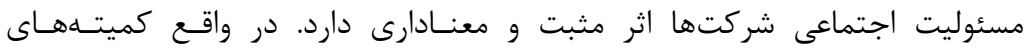

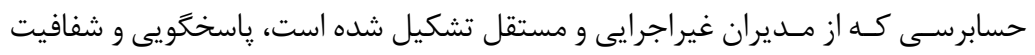


بهترى دارند و موجب مى شوند اعتبار ززارشكرى مالى و غيرمالى مانند افشاى مسئوليت

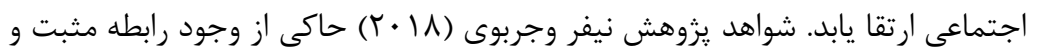

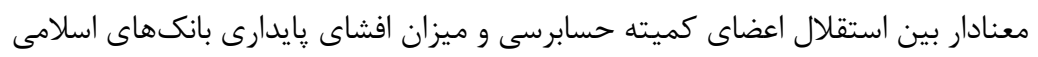

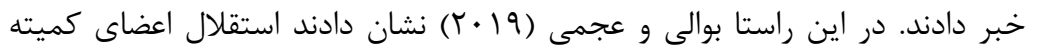

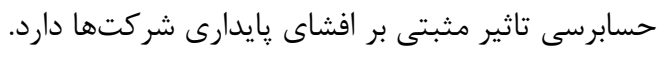

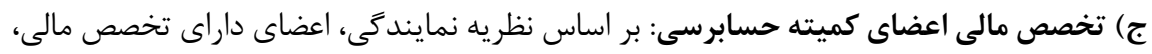

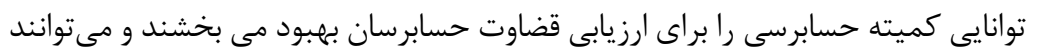

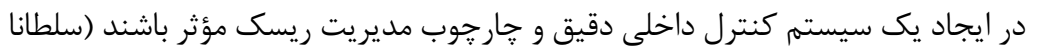

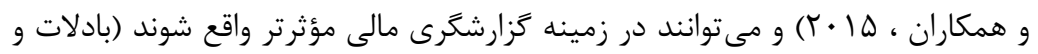

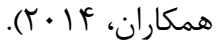

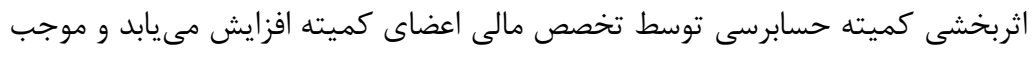

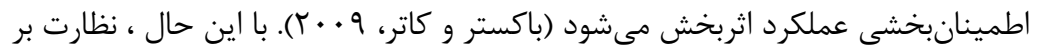

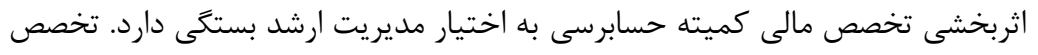

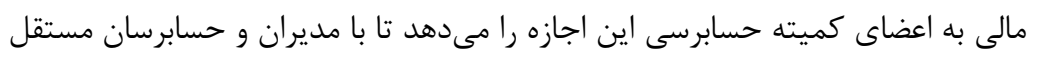

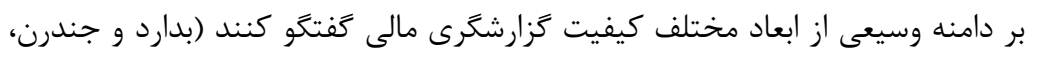

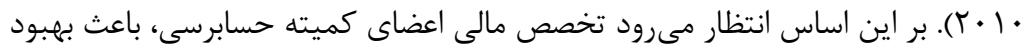

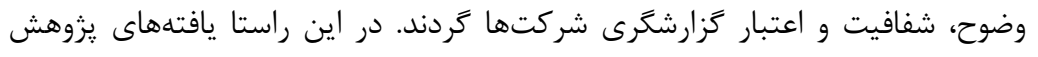

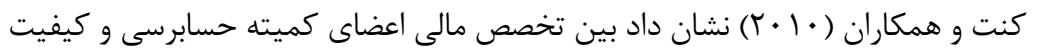

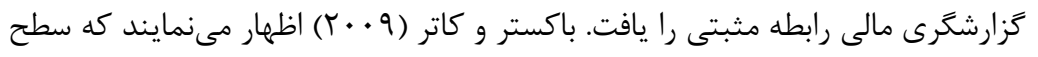

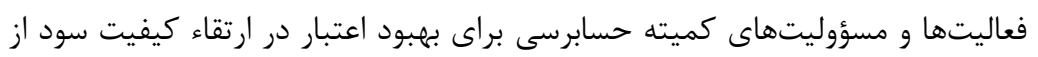

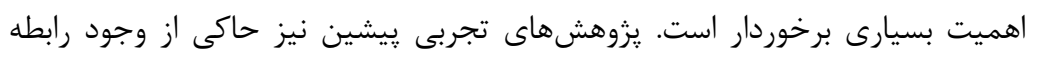

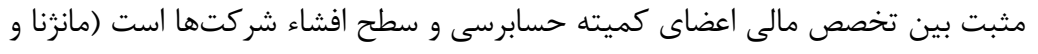

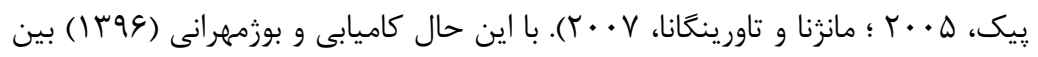
تخصص مالى اعضاى كميته حسابرسى و افشاى اختيارى رابطه معنادارى را مشاهد كاند ننمودند. آيوهامى و تاشاكور (T. V ) معتقدند اعضاى كميته حسابرسى با تخصص مالى احتمالا

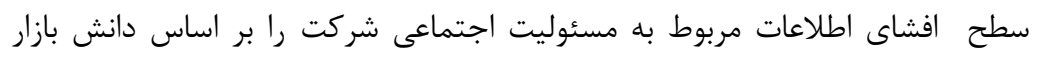

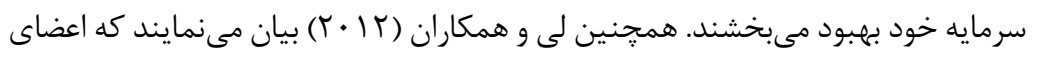

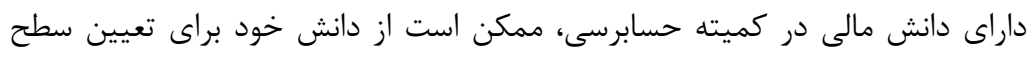

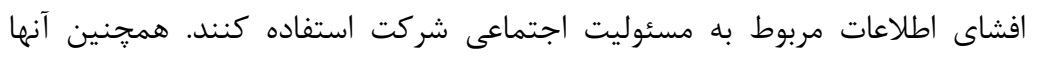




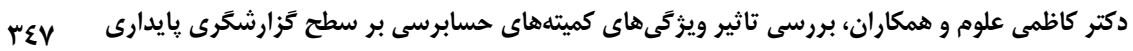

استدلال مىنمايند كه اعضاء داراى تخصص مالى در كميته حسابرسى در زمينه افشاى

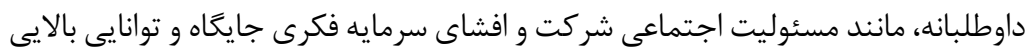

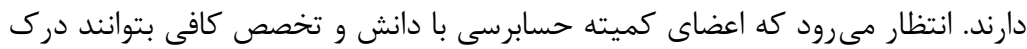
مناسبى از فعاليتهاى شركت داشته و سيس موجب ارزش إفزائى

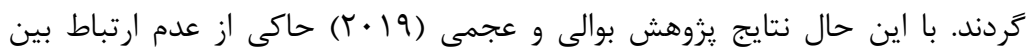

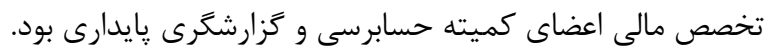
د) تنوع جنسيتى اعضاى كميته حسابرسى: حضور فعال زنان و مردان در هيئتمديره، كميتهها و

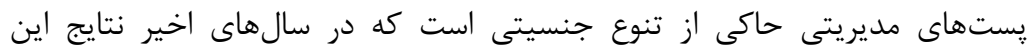

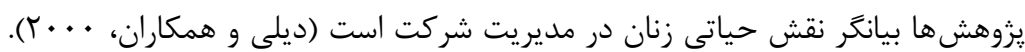

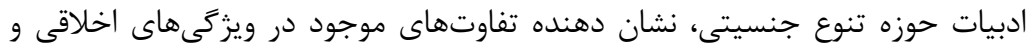

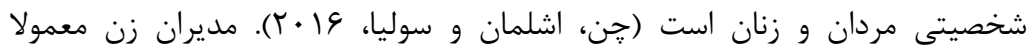

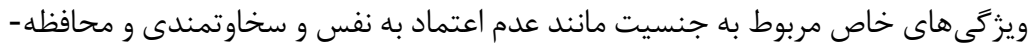
كارى را از خود نشان مى دهند و نسبت به مردان با احتمال بيشترى، سياستهاى

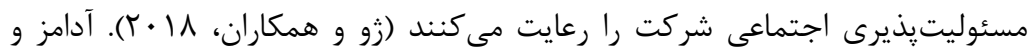

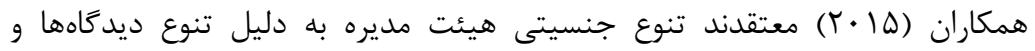

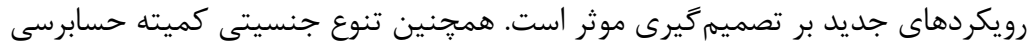

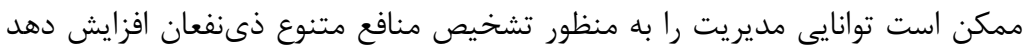

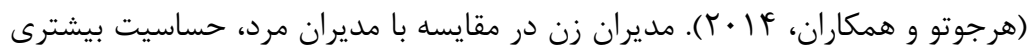

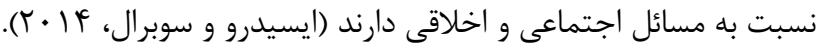

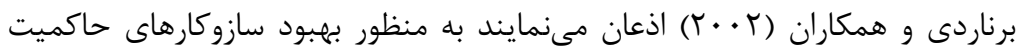

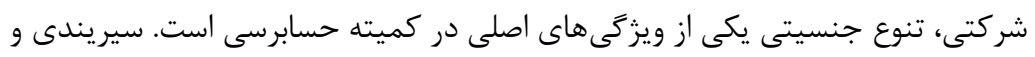

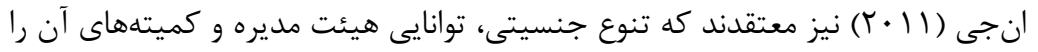

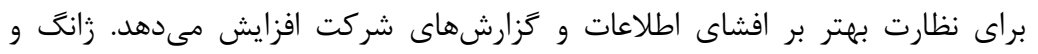

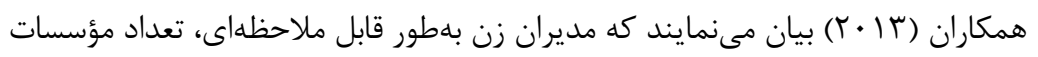

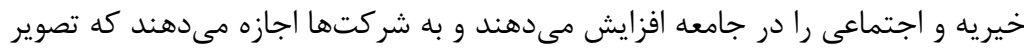

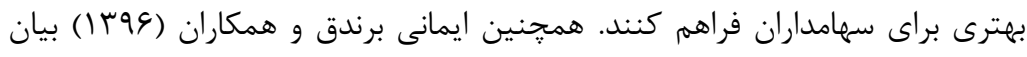

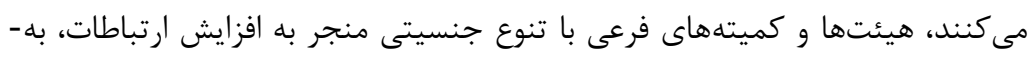

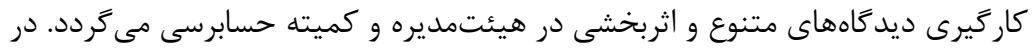

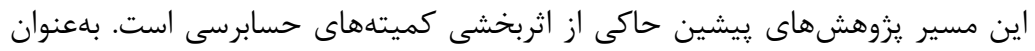

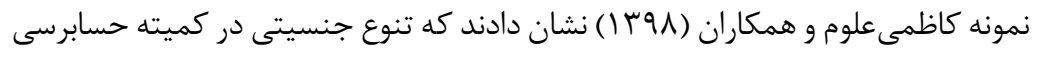




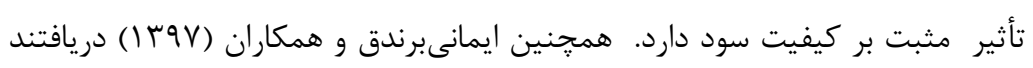

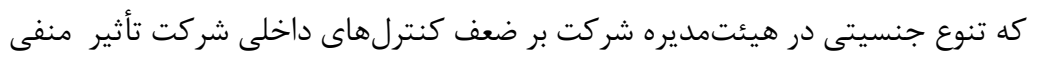

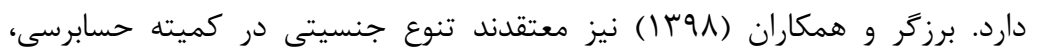

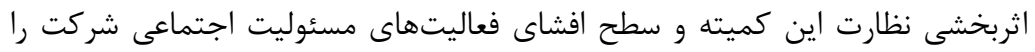

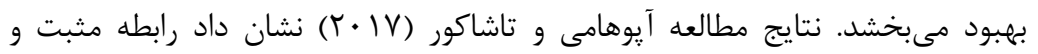

$$
\begin{aligned}
& \text { معنادارى بين تنوع جنسيتى اعضاى كميته حسابرسى و افشاى اطلاعات مسئوليت } \\
& \text { اجتماعى شركتها وجود دارد. در حوزه تنوع جنسيتى در اركان حاكميت شركتى و وإن }
\end{aligned}
$$

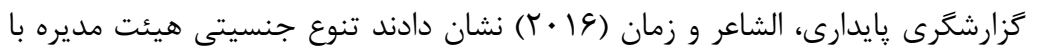

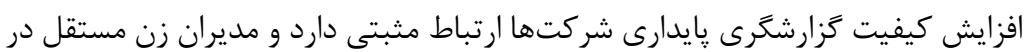

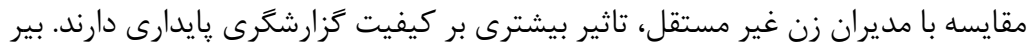

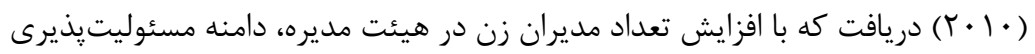

$$
\begin{aligned}
& \text { اجتماعى شركتى نيز افزايش مى يابد. }
\end{aligned}
$$

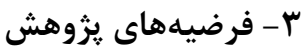

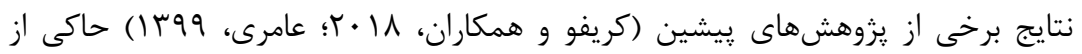

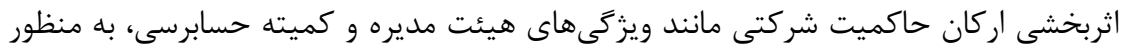

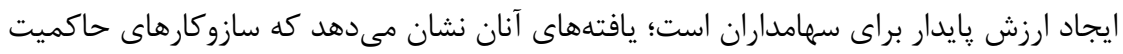

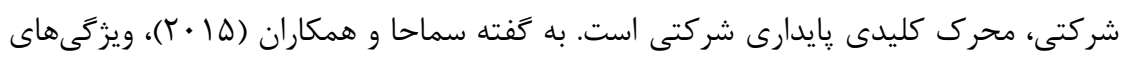

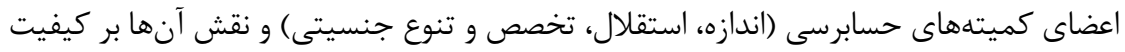

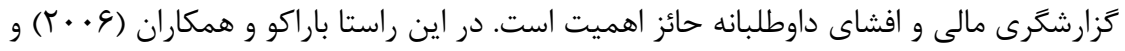

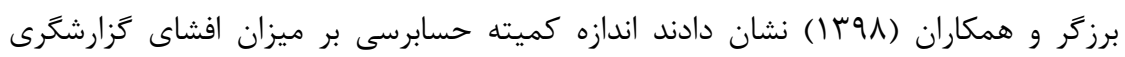

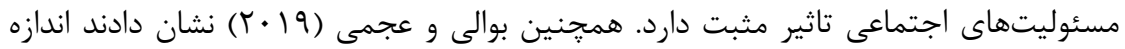

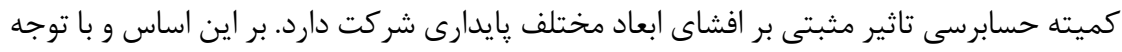

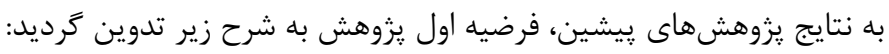

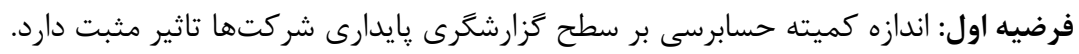

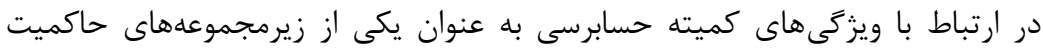

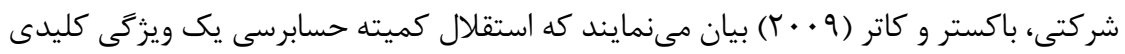

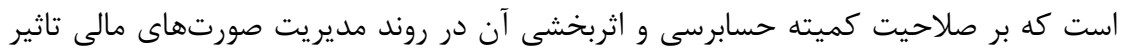

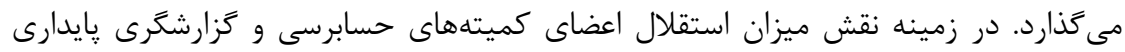

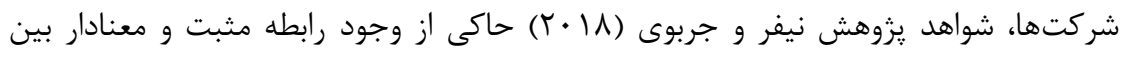




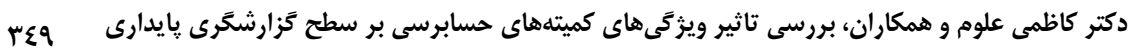

استقلال اعضاى كميته حسابرسى و ميزان افشاى پايدارى بانكهاى اسلامى بود. همجنين بوالى

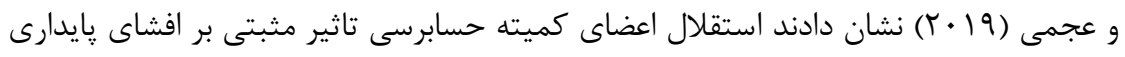

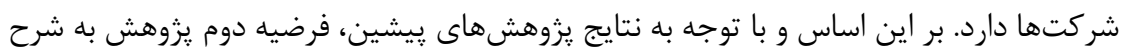

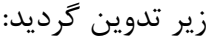
فرضيه دوم: استقلال اعضاى كميته حسابرسى بر سطح كَارشكَى يايدارى شركتها تاثير مثبت دارد.

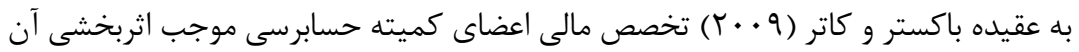

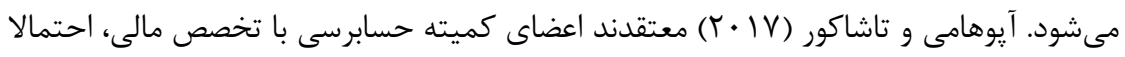

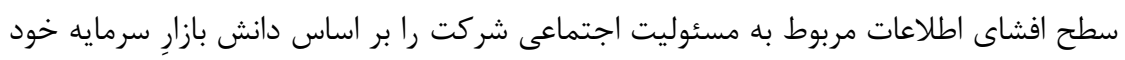

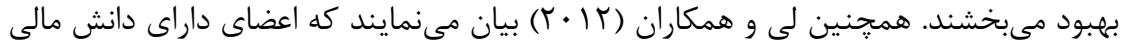

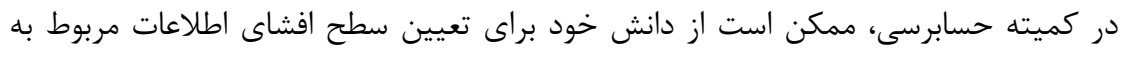

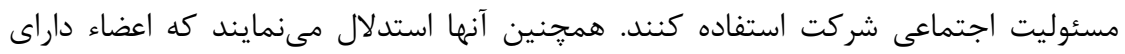

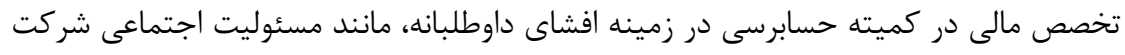

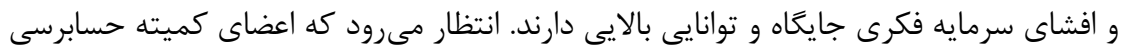

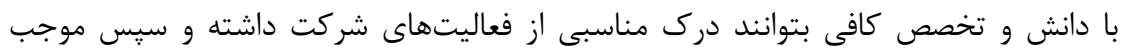

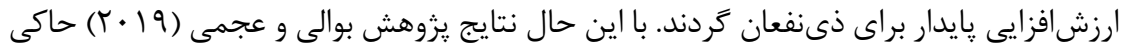

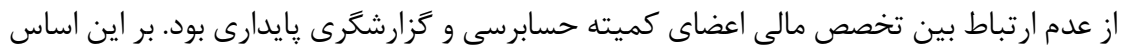

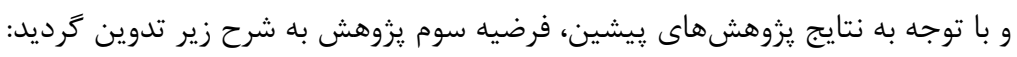

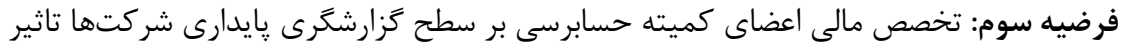

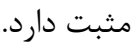

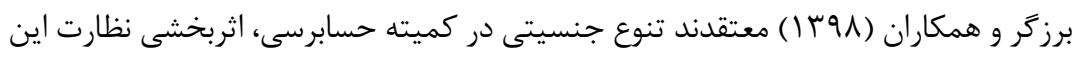

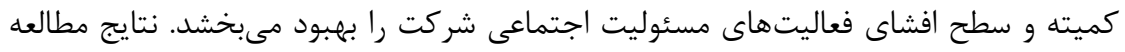

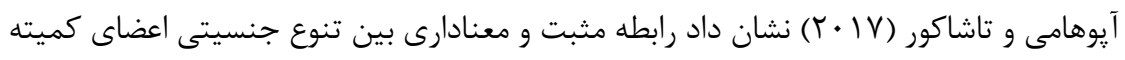

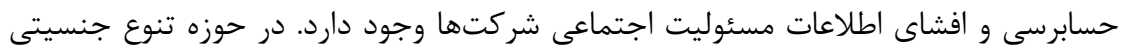

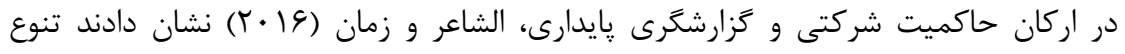
جنسيتى هيئت مديره با افزايش كيفيت كزارشكرى هايدارى

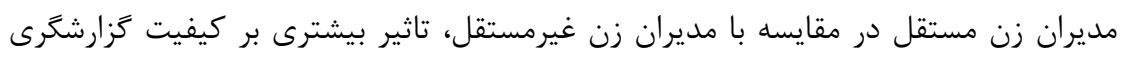

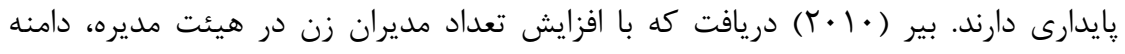

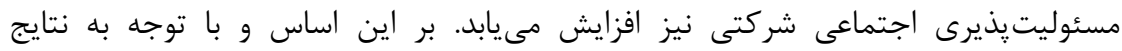

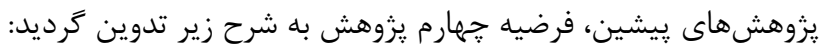




$$
\text { تاثير مثبت دارد. تنوارع جنسيتى اعضاى كميته حسابرسى بر سطح كزارشكرى پايدارى شركتها }
$$

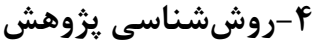

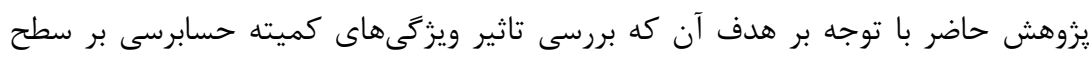

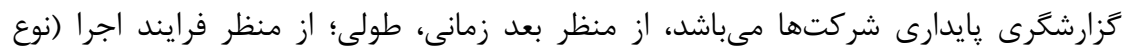

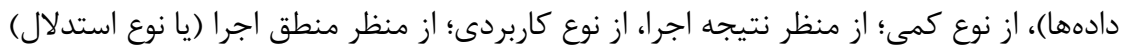

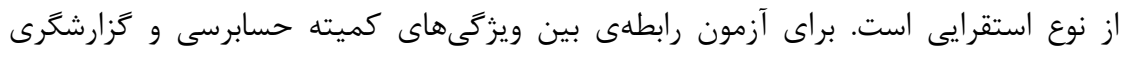

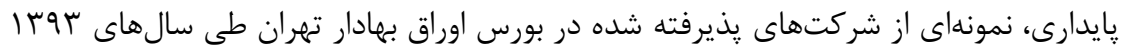

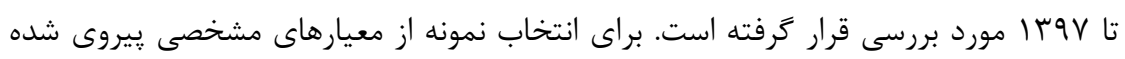

$$
\text { است. اين معيارها بدين شرح است: }
$$

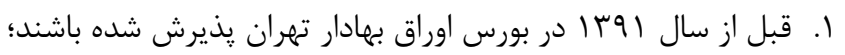

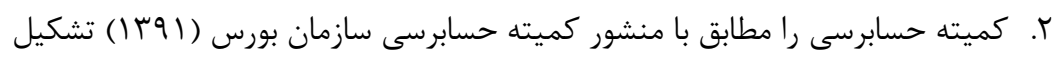

$$
\text { داده باشند؛ }
$$

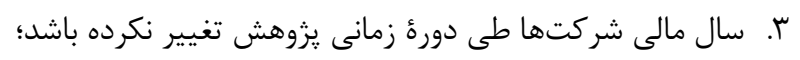

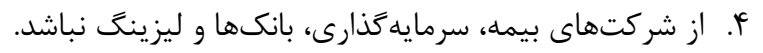

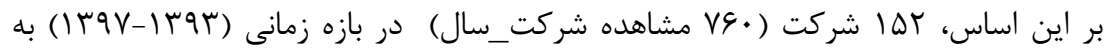

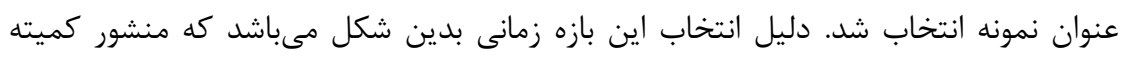

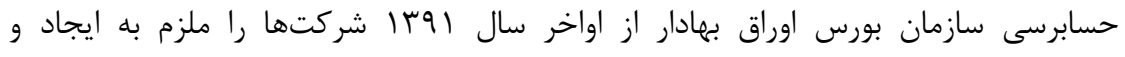

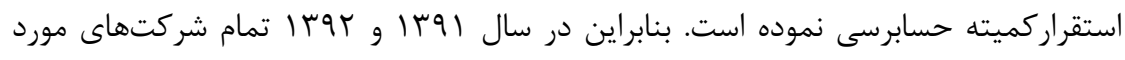

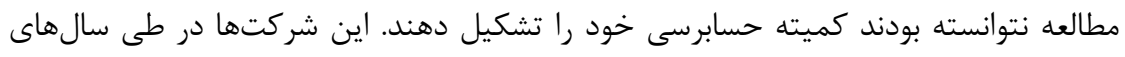

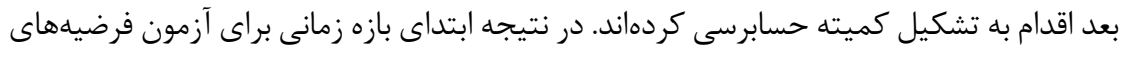

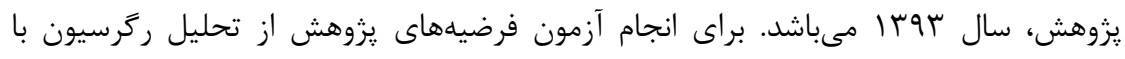

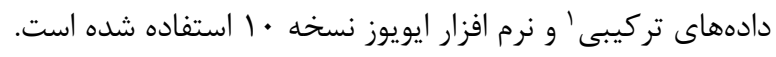

\section{مدل آزمون فرضيههاى يزوهش}

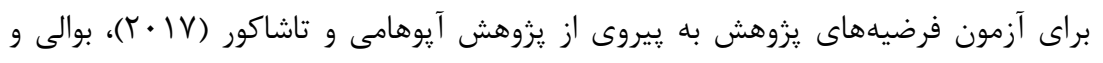

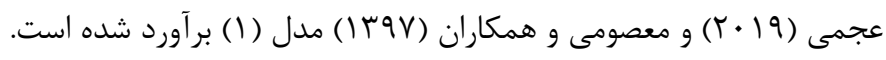

${ }^{1}$ Pooled Data 


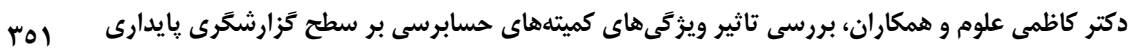

مدل (1) (- n)

SUSTAINABILITY i.t $_{\text {. }}$

$=\beta_{0}+\beta_{1}$ ACSIZE $_{i . t}+\beta_{2}$ ACINDEP $_{\text {i.t }}+\beta_{3}$ ACEXPERT $_{\text {i.t }}$

$+\beta_{4}$ ACGDIVERSITY $_{\text {i.t }}+\beta_{5}$ SIZE $_{\text {i.t }}+\beta_{6}$ ROA $_{\text {i.t }}$

$+\beta_{7} \mathrm{LEV}_{\mathrm{i} . \mathrm{t}}+\beta_{8} \mathrm{BSIZE}_{\mathrm{i} . \mathrm{t}}+\beta_{9} \mathrm{BIND}_{\mathrm{i} . \mathrm{t}}$

$+\beta_{10}$ CEO_CHAIR $_{\text {i.t }}+\beta_{11}$ SEASON $_{\text {i.t }}+\varepsilon_{\text {i.t }}$

متغير وابسته

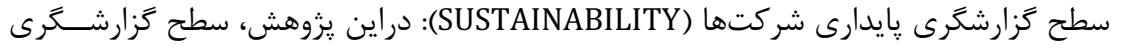

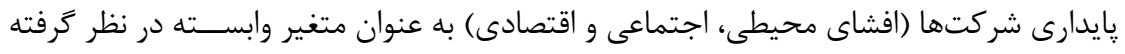

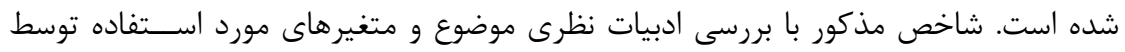

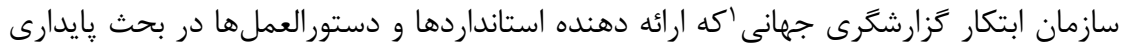

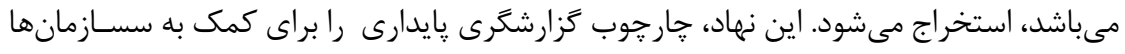

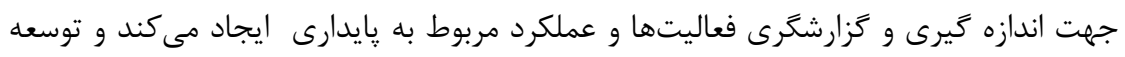

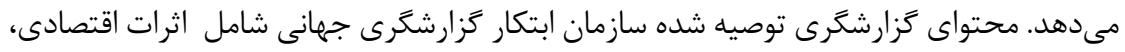

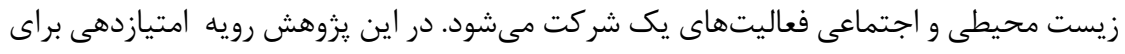

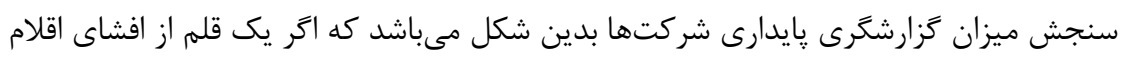

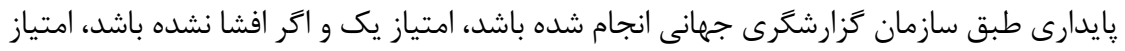

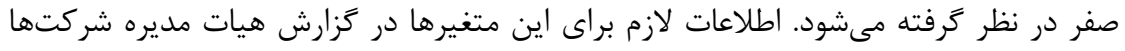

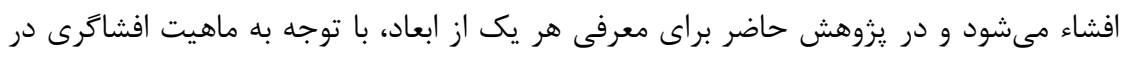

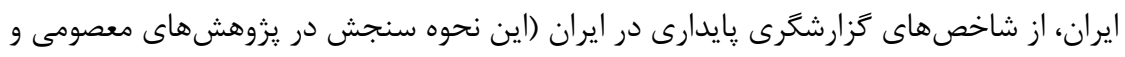

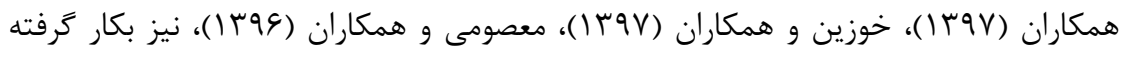

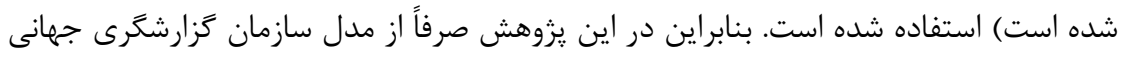

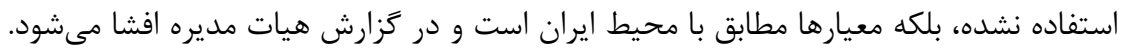

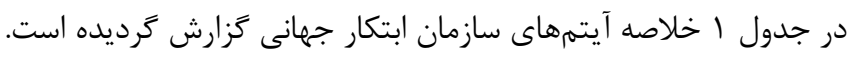

${ }^{1}$ Global Reporting Initiative (GRI) 


\begin{tabular}{|c|c|c|}
\hline \multicolumn{3}{|c|}{ جدول ا: خلاصه جگ ليست يايدارى سازمان ابتكار گزارشكرى جهانى } \\
\hline 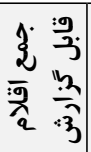 & اقلام تشكيل دهنده ابعاد يايدارى & $\begin{array}{l}\overline{3} \\
3 \\
\text { 3: } \\
\frac{3}{3}\end{array}$ \\
\hline \multirow{17}{*}{ IV } & افشاى گزيده اطلاعات صورتهاى مالى & \multirow{17}{*}{$\begin{array}{l}\frac{3}{3} \\
: \frac{9}{3} \\
3 \\
3 \\
3\end{array}$} \\
\hline & افشاى صورت ارزشافزوده & \\
\hline & افشاى آمار فروش مقدارى/ ريالى & \\
\hline & افشاى كزارشكرى اقتصادى در بخش جداگانه & \\
\hline & افشاى نسبتهاى مالى (بازده دارائى ها، بازده حقوق صاحبان سهام و ...) & \\
\hline & افشاى مقايسه بودجه مصوب با عملكرد واقعى & \\
\hline & افشاى سهم بازار شركت در كل صنعت و در منطقه بومى/ محلى & \\
\hline & افشاى رشد يا تغييرات سهم بازار و پيشبينى آن در آينده & \\
\hline & 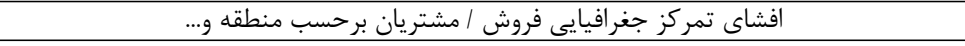 & \\
\hline & افشاى روند و تغييرات مقدارى / ريالى فروش برحسب محصولات/منطقه / مشتريان و .... & \\
\hline & افشاى روند و تغييرات تكنولوزى و مقرراتى اثركذار بر بازار و محصولات در منطقه يا محيط بومى & \\
\hline & افشاى تغييرات بازار و رقبا در صنعت و منطقه ( مزيت ها و فشار رقابتى) و جشم انداز آن & \\
\hline & افشاى وضعيت سهام و قيمت آن & \\
\hline & افشاى اثرات اقتصادى غيرمستقيم با اهميت از جمله صرفهجوئى ارزى و ..... & \\
\hline & ماليات ارزش افروده يرداخت شده محصولات و خدمات & \\
\hline & افشاى وضعيت مالياتى شركت & \\
\hline & افشاى يوشش اهداف و الزامات تعريف شده در برنامهريزىهاى شركت & \\
\hline \multirow{15}{*}{ If } & افشاى خطرات بالقوه فعاليتهاى شركت براى سلامتى انسان و محيطزيست & \multirow{15}{*}{$\begin{array}{l}3 \\
3 \\
3\end{array}$} \\
\hline & افشاى آموزش به كاركنان براى توليد با توجه به ملاحظات زيست محيطى و كاهش اثرات زيانبارش & \\
\hline & افشاى آموزش به مشتريان براى مصرف با توجه به ملاحظات زيست محيطى و كاهش اثرات زيانبار & \\
\hline & افشاى كزارشكرى محيطى در بخش جداكانه & \\
\hline & افشاى سياستهاى آتى محيطى شركت & \\
\hline & افشاى اقدامات جهت كاهش تاثير فعاليتها بر اقليمم & \\
\hline & افشاى استراتزىها، اقدامات جارى و برنامههاى آتى براى مديريت نمودن تاثيرات بر تنوع زيستى و & \\
\hline & 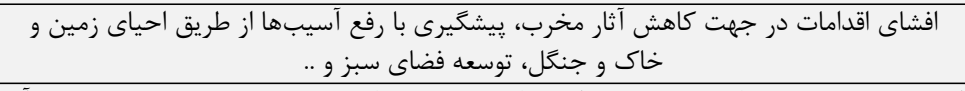 & \\
\hline & افشاى كل ضايعات و طبقهبندى به عنوان خطرناك و غيرخطرناك و نحوه دفع مناسب و كاهش آن & \\
\hline & افشاى ميزان آلودگى و اقدامات انجام شده براى كاهش انتشار گَازهاى گَلخانهاى سمى و ... & \\
\hline & افشاى دريافت گواهينامههاى تطابق سيستم مديريت محيطى و جوايز مربوط به رعايت مسائل & \\
\hline & افشاى آب مصرفى به تفكيك منبع و ميزان آنها، ميزان انرزى و آب صرفهجويى شده به دليل بهبود & \\
\hline & 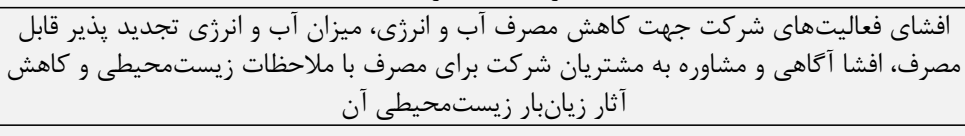 & \\
\hline & افشاى بركزارى يا شركت در همايشهاى زيستمحيطى، مانور محيطزيست و ... & \\
\hline & افشاى گزارش كنترل داخلى & \\
\hline
\end{tabular}




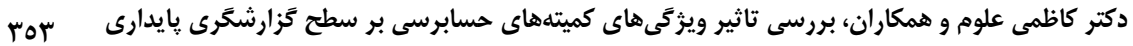

\begin{tabular}{|c|c|c|}
\hline \multirow{17}{*}{11} & افشاى گَزارش حسابرسى & \multirow{17}{*}{$\frac{3}{3}$} \\
\hline & افشاى خارجوب يكيارجه مديريت ريسك & \\
\hline & افشاى راهبرى شركتى در بخش جداكانه & \\
\hline & افشاى سياستهاى راهبرى آتى & \\
\hline & 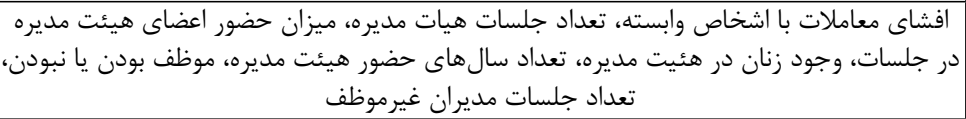 & \\
\hline & افشاى تعداد كميتهها، تعداد جلسات كميته ها & \\
\hline & افشاى كميته ريسك، كميته حسابرسى، كميته انتصابات و جبران عملكرد & \\
\hline & افشاى مديران مستقل هر كميته، نحوه انتخاب حسابرس و حسابرس جايكزين و حقالزحمه & \\
\hline & افشاى ميزان حقوق و مزايا و پاداش مديران، افشاى طرح جبران خدمات و ساير مزاياى مديران & \\
\hline & افشاى عوامل كيفى و كمى ارزيابى عملكرد مديران & \\
\hline & افشاى رعايت قوانين مرتبط تجارى و حقوقى & \\
\hline & افشاى دعاوى حقوقى يا انتظار دادخواهى قضايى شركت & \\
\hline & افشاى كدها و نظام نامهها و منشورهاى اخلاقى & \\
\hline & افشاى اقدامات شركت براى جلوگيرى و مبارزه با فساد، آموزش اخلاق حرفهاى & \\
\hline & افشاى ييشنهاد تقسيم سود متعلق به سهامداران & \\
\hline & افشاى اساسنامه، افشاى اطلاعات تماس و آدرس الكترونيكى و مسئول پاسخ كَويى سهام & \\
\hline & افشاى دستور العمل مالكيت سهام شركت توسط مديران و ... & \\
\hline \multirow{18}{*}{11} & افشاى فرايندها و سياستهاى ارتباط با كاركنان شركت و نظرسنجى از كاركنان و بررسى نتايج آن & \multirow{18}{*}{$\frac{3}{3}$} \\
\hline & افشاى كل ساعات آموزش، تشريح فعاليتها يا هزينه آموزش كل نيروى كار و .... & \\
\hline & افشاى كزارش عملكرد اجتماعى در بخش جداكانه، ارائه سياستهاى آتى اجتماعى & \\
\hline & 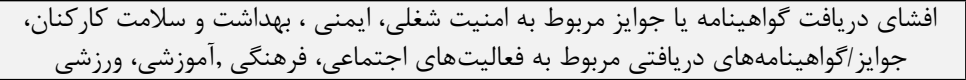 & \\
\hline & 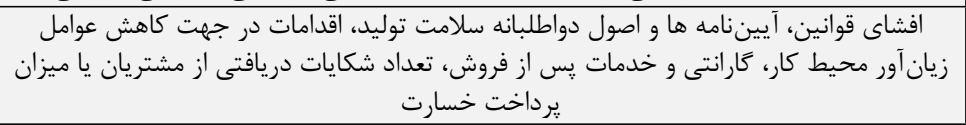 & \\
\hline & افشاى رويههاى مربوط به انتخاب تامين كنندًان & \\
\hline & 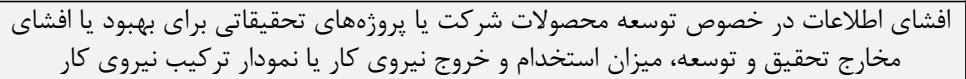 & \\
\hline & افشاى شكايات نيروى كار و يرداخت جرائم به آنها & \\
\hline & 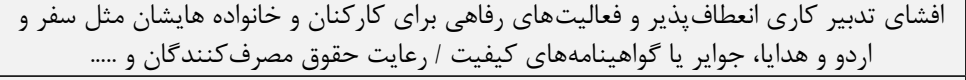 & \\
\hline & افشاى استاندارد ايمنى و سلامت كار & \\
\hline & 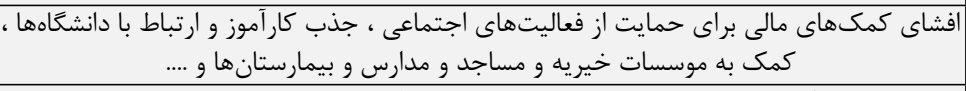 & \\
\hline & افشاى كمك هاى مالى به قربانيان بلاياى طبيعى و كشورهاى خارجى & \\
\hline & افشاى سيستم تخلفات، انتقادات و ييشنهادات، سيستمهاى مديريت رضايت مشتريان و اقدامات & \\
\hline & افشاى سياستها و رويههاى جذب و استخدام و پِاداش و ..... & \\
\hline & افشاى فعاليتهاى رفاهى كاركنان ( طرح خانه كارگرى، صندوق رفاه كار كنان و بيمه عمر و ....) & \\
\hline & افشاى ايجادزيرساخت براى عموم مردم درجامعه ومنطقه بومى / محلى ازجمله احداث يل، جاده و.... & \\
\hline & افشاى تشريح اقدامات انجام شده براى جلوكيرى و مقابله با فساد، رشوهخوارى و يولشوئى & \\
\hline & افشاى كل كاركنان بر حسب نوع استخدام، گروه سنى، منطقه جغرافيايى، جنسيت، تحصيلات و & \\
\hline
\end{tabular}




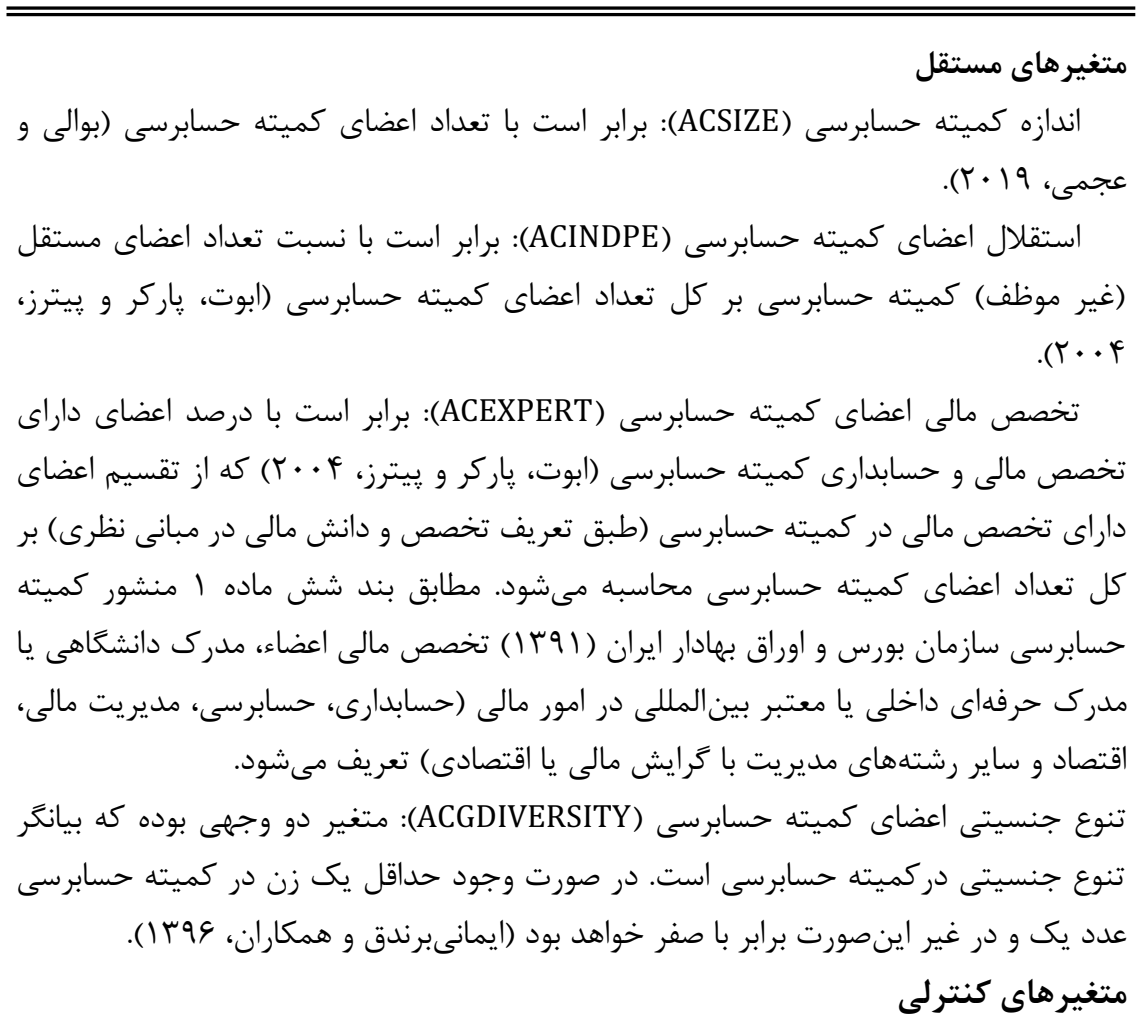

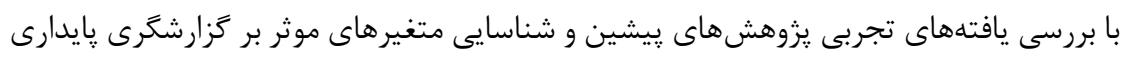

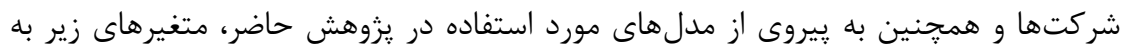
عنوان متغيرهاى كنترلى انتخاب شدند.

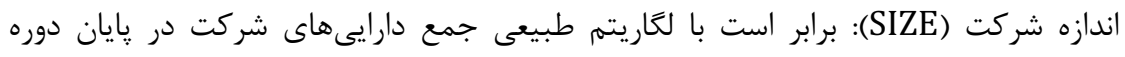

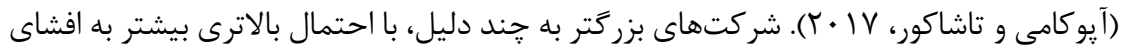

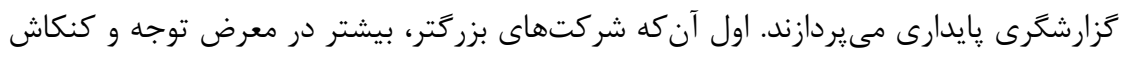

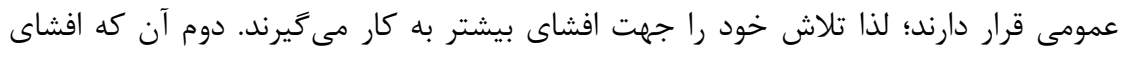

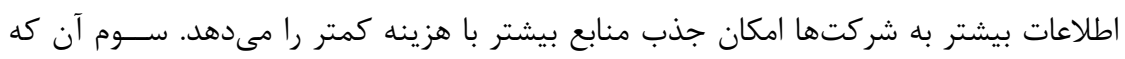

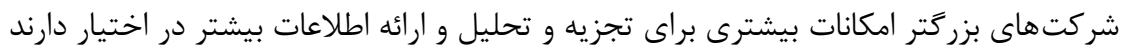

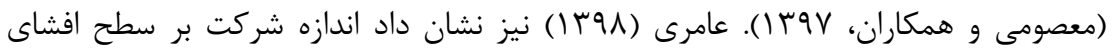
كزارش קايدارى شركتها تأثير معنادارى دارد.

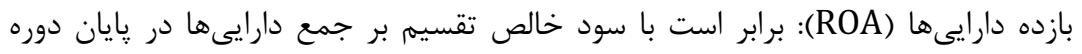

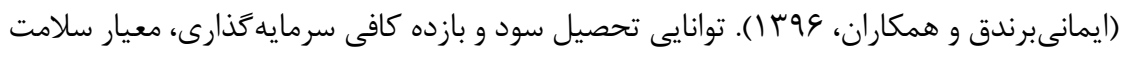


مالى و مديريت مؤثر شركت است. معمولاً سرمايهكذاران تمايل به سرمايهَذارى در شركتهايى

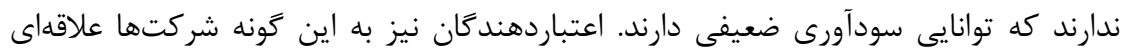

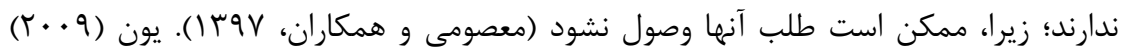

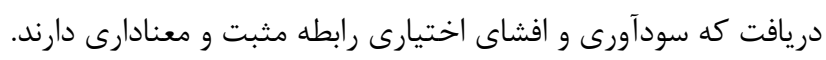

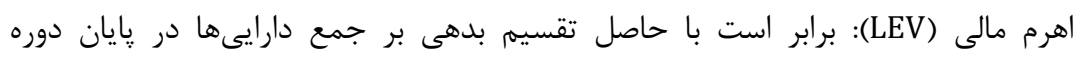

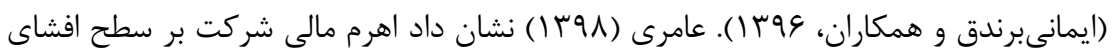

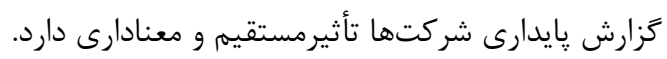

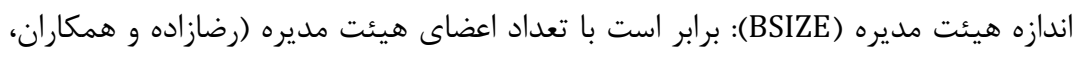

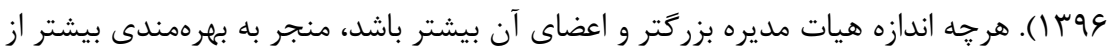

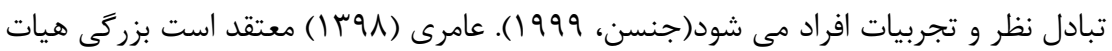

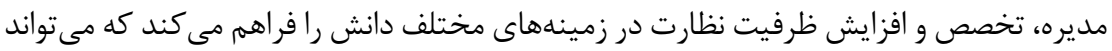

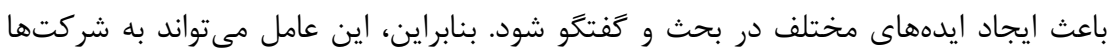

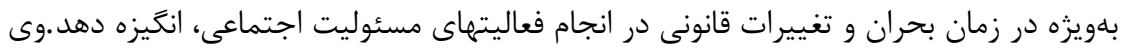

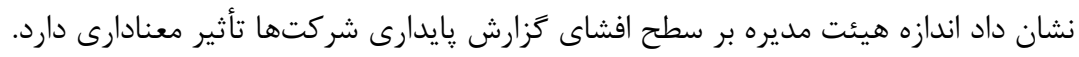

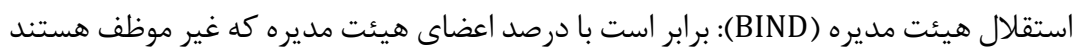

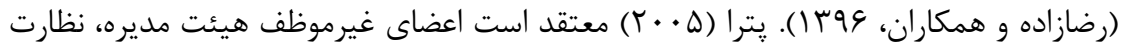

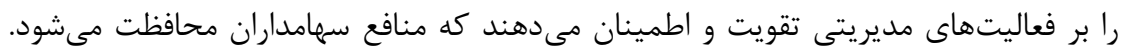

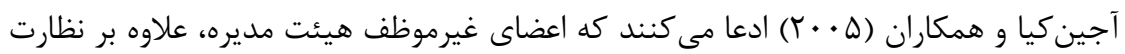

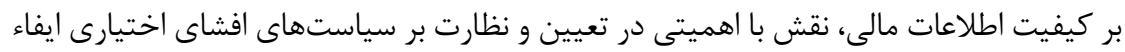

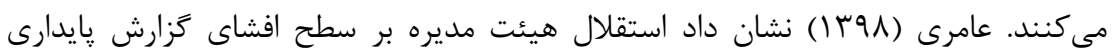
شركتها تأثير معنادارى دارد.

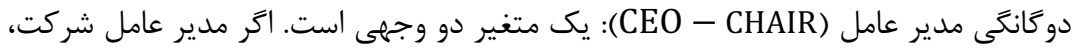

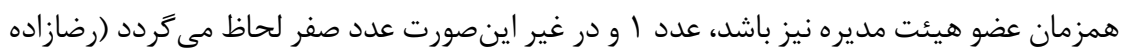

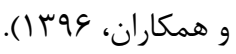
فصل(SEASON)كنترل اثر بايان سال مالى منتهى به اسفند ماه شركتها بوده و يكى متغير

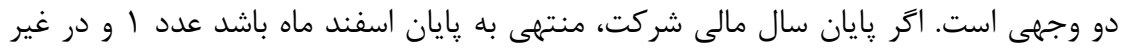

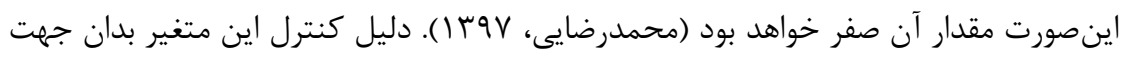

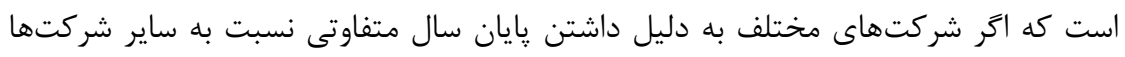

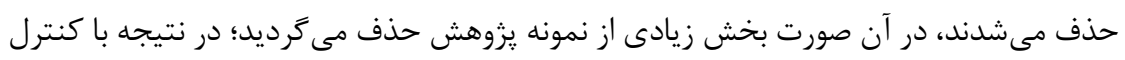

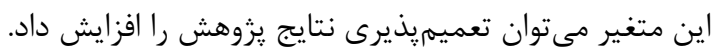




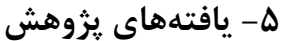

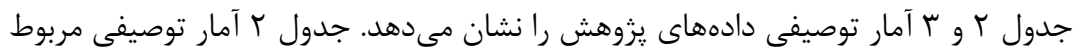

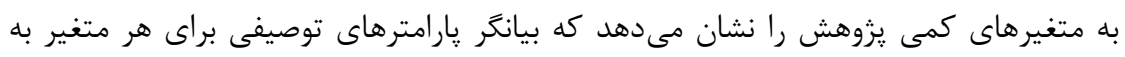
صورت جداكانه است. براى سنجش متغير افشاى اطلاعات پايدارى از ابعاد اقتصادى، محيطى،

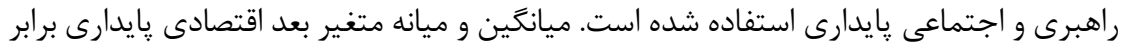

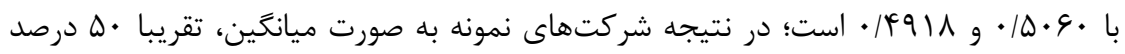

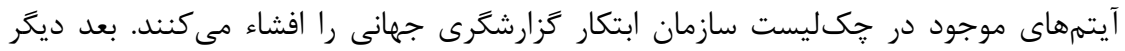

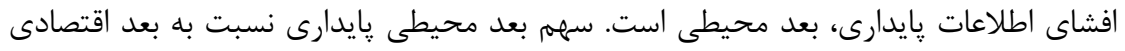

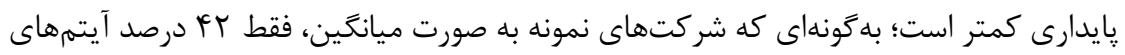

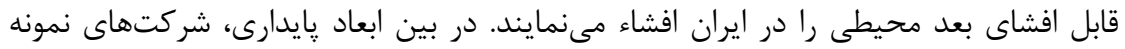

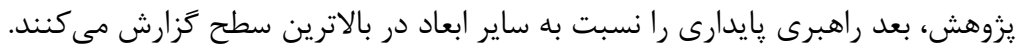

\begin{tabular}{|c|c|c|c|c|c|c|c|}
\hline كشيدكى & 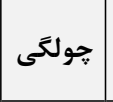 & انحراف & حداقل & حداكثر & 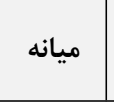 & ميانغين & 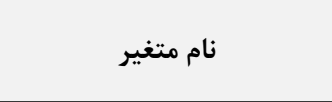 \\
\hline T/TrAT & $-\cdot \cdot \cdot \Delta \vee G$ &.$/ 11 \mathrm{kT}$ & $\cdot / \pi \backslash \Delta \Lambda$ & $\cdot / V T I Q$ & $\cdot / 4911$ & $\cdot 10 \cdot 9$ & بعد اقتصادى پايدارى \\
\hline r/THES & $-\cdot \cdot \cdot \Delta r V$ & $\cdot 1 \cdot 9 \Delta \wedge$ & . & $\cdot 191 .$. & . / &.$/ F I T \Delta$ & بعد محيطى پايدارى \\
\hline r/IVFq & $\cdot / \cdot r \Delta \cdot$ & $\cdot / \cdot \wedge \varphi$ & - IMEST & $\cdot / V \Lambda I f$ &.$/\left.091\right|^{f}$ & - $19 \Delta \mu \Lambda$ & بعد راهبرى پايدارى \\
\hline T/ITHF & .1. FTG & $\cdot / \cdot \vee \wedge 1$ & - & . IGYGF & $\cdot / \pi I \Delta V$ & $\cdot / r \Delta I V$ & بعد اجتماعى پايدارى \\
\hline$r / \backslash \Delta V \varphi$ & $.1 \cdot 4 \wedge 9$ & . IVAT & $\cdot / \pi \cdot 10$ & • & .1019. &.$/ 4 \lambda I r$ & 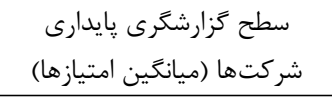 \\
\hline$r|9| \cdot r$ & $.1 .9 \wedge \mathrm{F}$ & I/FFET & $r / \ldots$ & $\Delta / \cdots$ & $r / \ldots$ & r/rN19 & اندازه كميته حسابرسى \\
\hline r/VEVE &.$/ \cdot 1 r \Lambda$ &.$/$ mq9 & • & $1 / \cdots$ & $\cdot 19 V \cdot$. & .10190 & استقلال اعضاى كميته حسابرسى \\
\hline$r / \mathrm{V} \Delta \Lambda \Lambda$ & $-\cdot / \cdot 411$ & ./r१マब & • & $1 / \cdots$ & $\cdot 19 V \cdot$. & . $/ \Delta r \Delta q$ & تخصص مالى اعضاى كميته \\
\hline r/VFEV & . I. TET & I/TFth & $|r / 1 \cdot 1|$ & IV/4\&9Y & $1 r / 94 \wedge V$ & $\| F / \mid \Delta \Delta \wedge$ & اندازه شركت \\
\hline$r / .9 \vee \Delta$ & $.198 \wedge r$ & . MTIK & $-\cdot / 1 \cdot r \varepsilon$ & $\cdot / T V M F$ & .1 .914 & $\cdot / 1 \cdot V F$ & بازده دارايىها \\
\hline r/ArFA & $-\cdot / 4 \cdot 9 T$ & $\cdot / 1 \wedge \varepsilon$. & $\cdot|r \Delta H|$ & . /VrqT & $\cdot 1 \Delta 9 \Delta \Delta$ & $.109 \& 9$ & 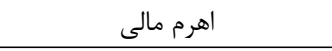 \\
\hline$r / 1494$ & $.1 .4 r q$ &.$/ 419 V$ & $\Delta / \cdots$ & $\mathrm{V} / \cdots$ & $\Delta / \cdots$ & D/.TTF & اندازه هيئت مديره \\
\hline K/ADSV & $\cdot \mid \cdot+11$ & $\cdot / 1 / 94$ & $\cdot / r \cdots$ & $1 / \cdots$ & $\cdot 19 \ldots$ & - $1991 \mathrm{H}$ & اعضاى غير موظف هيئت مديره \\
\hline
\end{tabular}

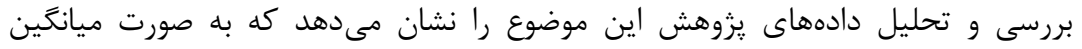

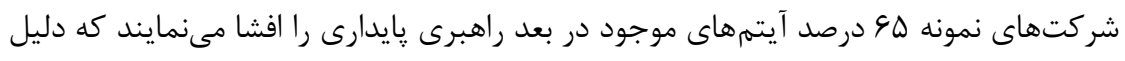

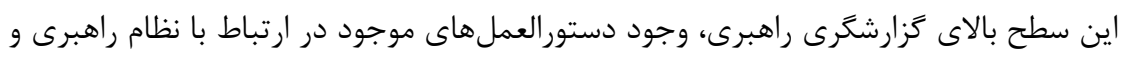




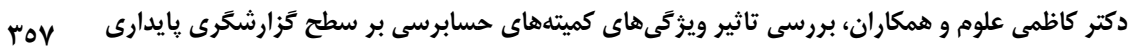

حاكميت شركتى تدوين شده توسط سازمان بورس اوراق بهادار است. همجنين ميانكين بعد

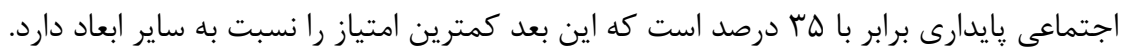

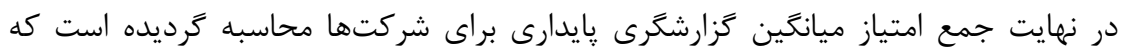

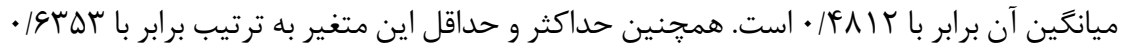

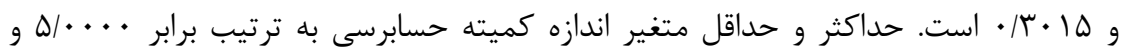

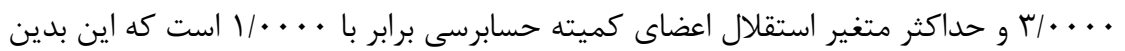
مفهوم است كه در برخى از مشاهدات، تمام اعضاى كميته حسابرسى، عضو غيرموظف بودهاند.

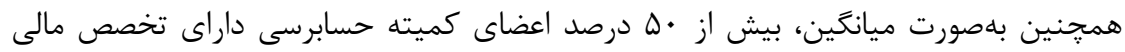

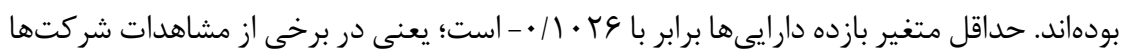

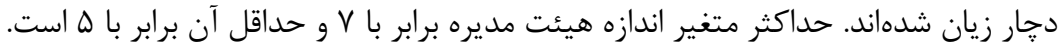

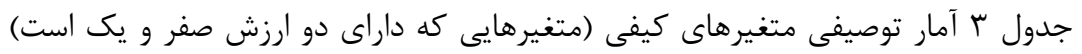

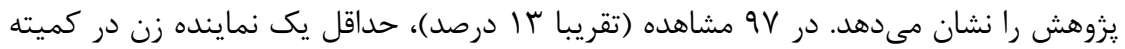

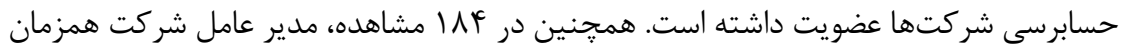
عضو هيئت مديره نيز بوده است. جدول r. آمار توصيفى دادهاى كيفى يزوهش

\begin{tabular}{|c|c|c|c|c|c|c|}
\hline \multicolumn{2}{|c|}{ جمع } & \multicolumn{2}{|c|}{ وجود } & \multicolumn{2}{|c|}{ عدم وجود } & \multirow{2}{*}{ نام متغير } \\
\hline 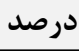 & 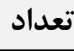 & درصد & 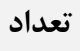 & درصد & 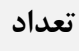 & \\
\hline $1 \cdots$ & VG. & TY/AV & ब\& & $V G / T$ & १७ & تنوع جنسيتى اعضاى كميته حسابرسى \\
\hline $1 \cdots$ & VG. & V৭/V & $\Delta \vee G$ & $r I / T H$ & $111 F$ & دوگانگىى مدير عامل \\
\hline
\end{tabular}

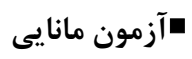

قبل از برآورد مدل، ابتدا بايد پإيايى متغيرهاى يزوهش رائ را مورد بررسى قرار داد. پايايى بدين

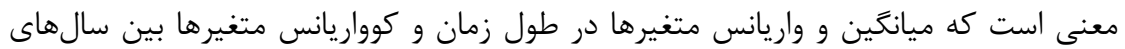

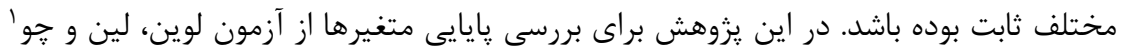

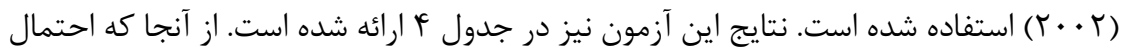

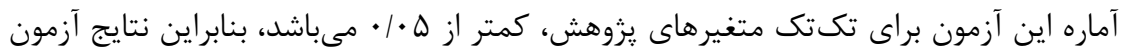

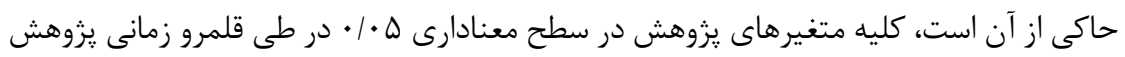

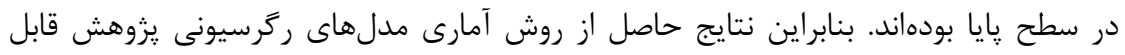

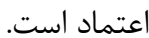

${ }^{1}$ Levin, Lin and Chv 


\begin{tabular}{|c|c|c|c|}
\hline \multicolumn{4}{|c|}{ جدول أ. آزمون لوين، لين و جو } \\
\hline لوين، لين و ٪ال آماره & لين آماره لوين، & تعداد وقفه & 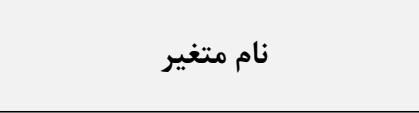 \\
\hline$\cdot / \cdots$ & $-\mid F / T r \wedge \Delta$ & $\left(\mathrm{I}_{0}\right)$ & سطح گزارشخرى گايدارى شركتها \\
\hline$\cdot 1 \cdot \cdots$ & -9/ATFT & $\left(\mathrm{I}_{0}\right)$ & اندازه كميته حسابرسى \\
\hline$\cdot 1 \cdot \cdots$ & -TE/GTG. & $\left(\mathrm{I}_{0}\right)$ & استقلال اعضاى كميته حسابرسى \\
\hline$\cdot 1 \cdots$ & $-r F / q \wedge r \Delta$ & $\left(\mathrm{I}_{0}\right)$ & تخصص مالى اعضاى كميته حسابرسى \\
\hline$\cdot 1 \cdot 419$ & $-1 / \wedge \Delta \mu q$ & $\left(\mathrm{I}_{0}\right)$ & ننوع جنسيتى اعضاى كميته حسابرسى \\
\hline$\cdot 1 \cdots$ & $-Y N / 9 \Delta V I$ & $\left(\mathrm{I}_{0}\right)$ & 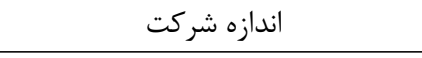 \\
\hline$\cdot 1 \cdot \cdots$ & $-\Delta r / \cdot V r \Lambda$ & $\left(\mathrm{I}_{0}\right)$ & بازده دارايىها \\
\hline$\cdot 1 \cdots$ & $-r \cdot / r \Delta q r$ & $\left(\mathrm{I}_{0}\right)$ & 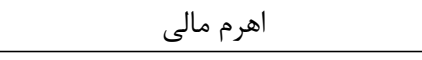 \\
\hline$\cdot 1 \cdots$ & $-1 \cdot 1 \cdot 191$ & $\left(\mathrm{I}_{0}\right)$ & اندازه هيئت مديره \\
\hline$\cdot 1 \cdots$ & $-V / 1 T / 9$ & $\left(\mathrm{I}_{0}\right)$ & اعضاى غيرموظف هيئت مديره \\
\hline$\cdot \cdot \cdot 14$ & 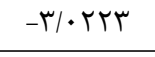 & $\left(\mathrm{I}_{0}\right)$ & دو مانكى مدير عامل \\
\hline
\end{tabular}

\section{آزمون هم انباشتخَى}

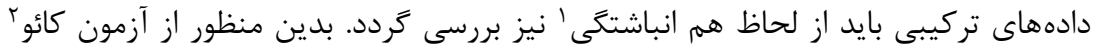

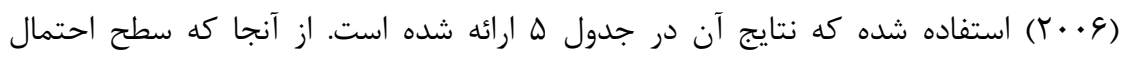

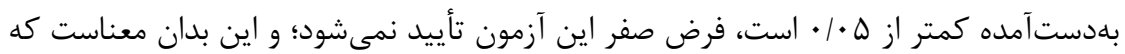

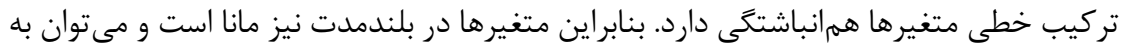

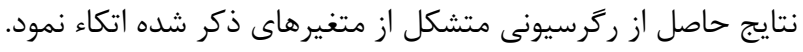

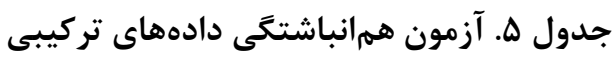

\begin{tabular}{|c|c|c|}
\hline احتمال & آمارة t & مدل \\
\hline$\cdot 1 \cdot \ldots$ & $1 \cdot / r \Delta F$. & مدل (1) \\
\hline
\end{tabular}

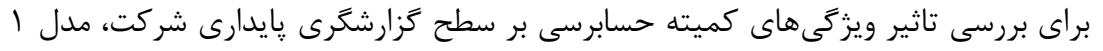

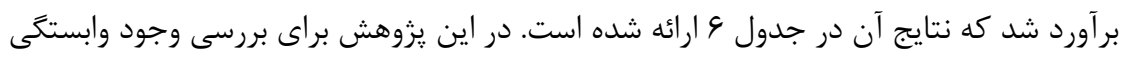

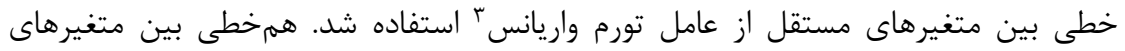

${ }^{1}$ Cointegration

${ }^{2} \mathrm{KaO}$

${ }^{3}$ VIF 


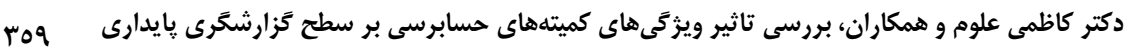

توضيحى در مدل هاى جند متغيره موجب مى شود كه ضرايب متغيرهاى توضيحى بىمعنى شوند.

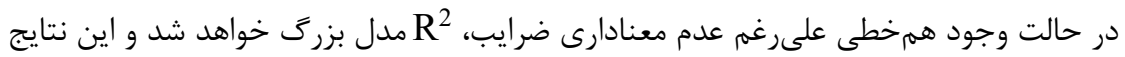

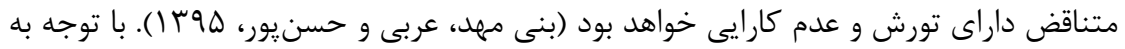

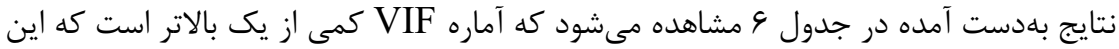

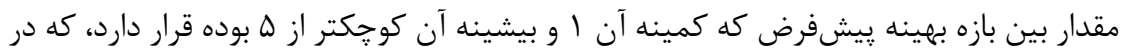
حالت كلى عدم همخطى بين متغيرهاى مستقل يزوهش را نشان مي دهد.

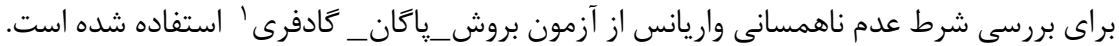

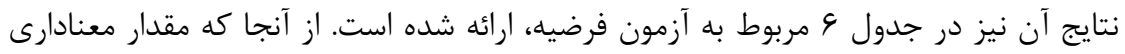

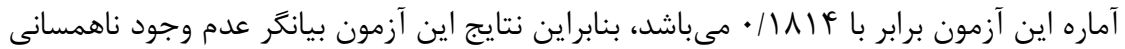

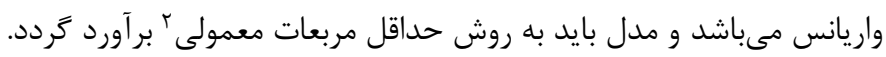

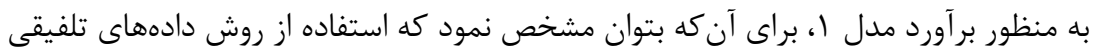

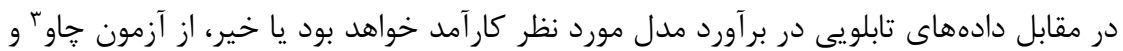

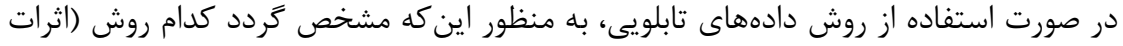

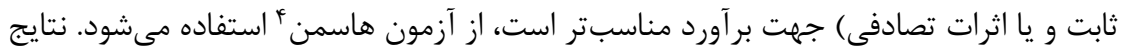

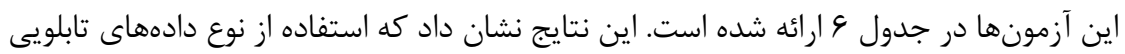

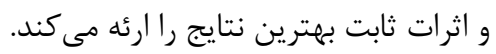
در اين يزوهش به منظور سنجش نرمال بودن خطاى يُماند، آزمون جارك-براه (1911)

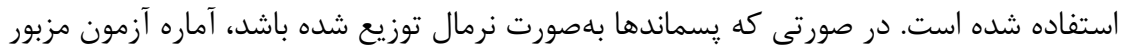

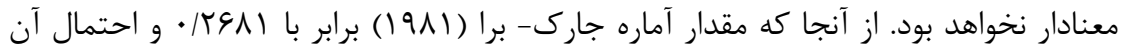

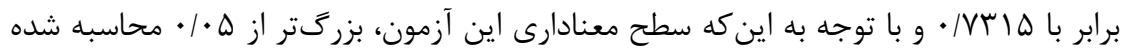

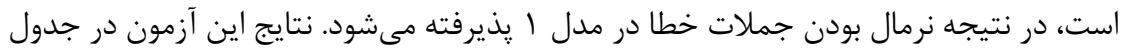
ع ارائه شده است. به منظور بررسى استقلال خطاها از يكديخر از آزمون دوربين-واتسون \& استفاده شده كه نتايج

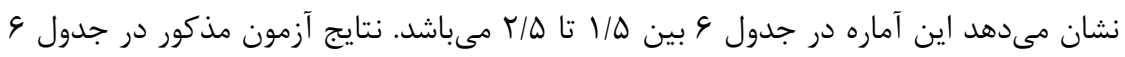

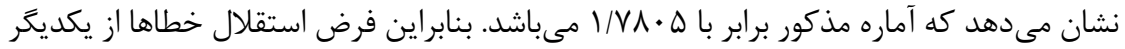

${ }^{1}$ Breusch-Pagan-Godfrey

${ }^{2}$ OLS

${ }^{3}$ Chow

${ }^{4}$ Hausman

${ }^{5}$ Jarque-Bera

${ }^{6}$ Dorbin Watson 


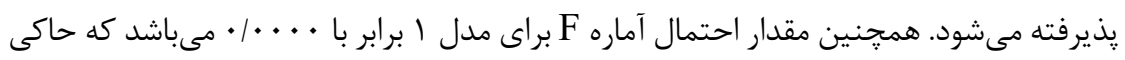

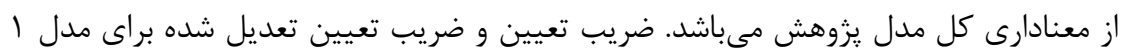

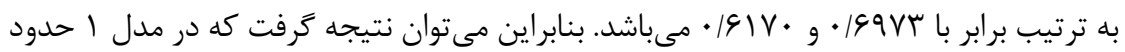

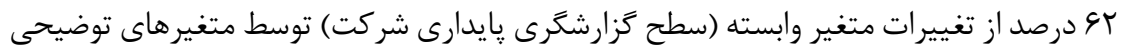
مدل ا توضيح داده مىشوند. جدول 9. تاثير ويزَّىهاى كميته حسابرسى بر سطح كزارشَّى بايدارى شركت

\begin{tabular}{|c|c|c|c|c|c|}
\hline \multicolumn{6}{|c|}{ 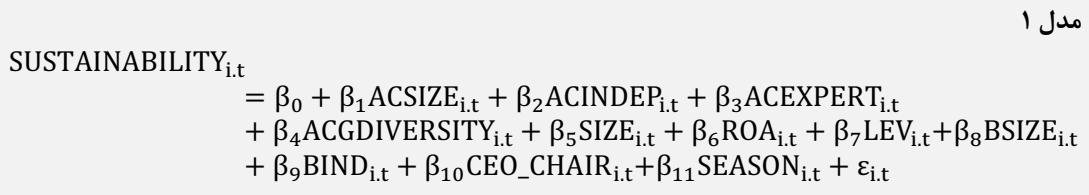 } \\
\hline $\begin{array}{l}\text { همخطى } \\
(\text { VIF) }\end{array}$ & 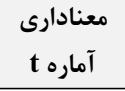 & 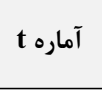 & ضريب بر آورده شده & \multicolumn{2}{|c|}{ متغير توضيحى } \\
\hline I/TrTa & . / IfAr & I/FFVI & (. & \multirow{2}{*}{\multicolumn{2}{|c|}{ استقازه كميته حسابرسى اعضاى كميته حسابرسى }} \\
\hline $1 / \cdot 911$ & $.1 \cdots$ & $\Delta / r q \vee \Delta$ & $\cdot 11 \cdot 1$ & & \\
\hline 1/1r৭9 & $\cdot 1 \cdot \cdots$ & $Y / \Delta \wedge \vee \wedge$ & $\cdot|\cdot T r|$ & \multicolumn{2}{|c|}{ تخصص مالى اعضاى كميته حسابرسى } \\
\hline 1/9VGT & $\cdot 1 \cdot \cdots$ & V/TFa. & $\cdot / \cdot \Delta H V$ & \multicolumn{2}{|c|}{ تنوع جنسيتى اعضاى كميته } \\
\hline 1/9rkT & $\cdot 1 \cdot \cdots$ & $r / 9 \Lambda \cdot r$ &.$\cdot \cdot r \mu$ & & اندازه شركت \\
\hline $1 / 194 V$ & $\cdot 1 \cdot \cdots$ & r/qAVV &.$|\cdot+4|$ & & بازده دارايىها \\
\hline $1 / 19 \vee \Delta$ & $\cdot 1 \cdot \cdots$ & V/D9AF & $\cdot / r 194$ & & اهرم مالى \\
\hline I/IVGT & $\cdot / T V V V$ & $1 / \cdot \wedge \& 4$ &.$/ .4 I V$ & & اندازه هيئت مديره \\
\hline 1/DVQT & $\cdot 1 \cdot \cdots$ & $r / \cdot \Delta \cdot V$ & $.1 \cdot 119$ & \multicolumn{2}{|c|}{ اعضاى غيرموظف هيئت مديره } \\
\hline- & $\cdot 1 \cdot \cdots \cdot 1$ & r/AIVF &.$|\cdot r t|$ & \multicolumn{2}{|r|}{ مقدار ثابت } \\
\hline 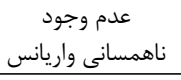 & روشيجه آزمون & $\cdot / 1 \Lambda 1 F$ & 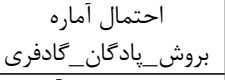 & T/ArFV & بروش_يادكان__ادفرى \\
\hline 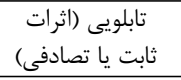 & نتيجه آزمون & $\cdot / \ldots$ & $\begin{array}{c}\text { سطح معنادارى آزمون } \\
\text { "جاو } \\
\end{array}$ & N/trtr & آماره آزمون خاو \\
\hline اثرات ثابت & نتيجه آزمون & $\cdot 1 \cdot \cdots$ & سطح معنادارى آزمون & $8 r / \cdots q$ & آماره آزمون هاسمن \\
\hline جمال بودن & نتيجه آزمون & $\cdot / V T I D$ & 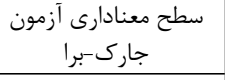 & $\cdot \mid r \& \wedge 1$ & آماره آزمون جارك-برا \\
\hline $1 / V \Lambda \cdot \Delta$ & $\begin{array}{l}\text { آماره دوربين } \\
\text {-واتسون }\end{array}$ & $.191 \mathrm{~V}$ & ضريب تعيين تعديل & •/99Vr & ضريب تعيين \\
\hline كنترل شده است. & سال مالى & $\cdot 1 \cdot \cdots$ & Fعنادارى آماره F F F F & N/DQVF & 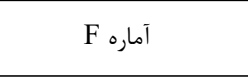 \\
\hline
\end{tabular}


دكتر كاظمى علوم و همكاران، بررسى تاثير ويثَى هاى كميتهاى حسابرسى بر سطح تَزارشكَى بايدارى اجب

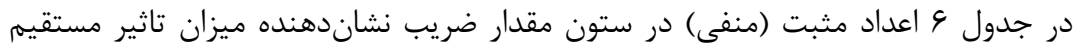

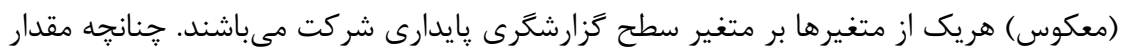

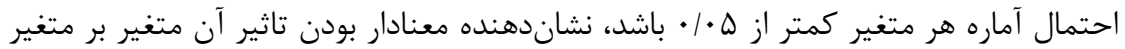
وابسته (سطح گزارشكَى پايدارى شركت) است.

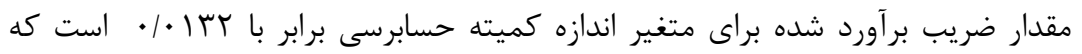

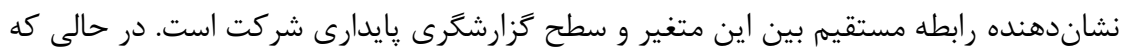

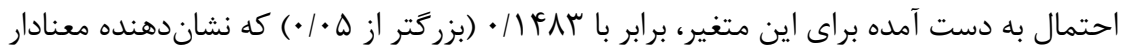

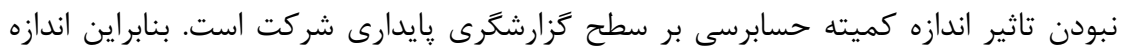

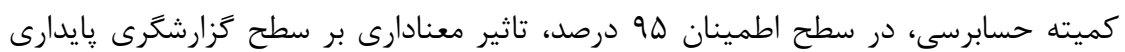

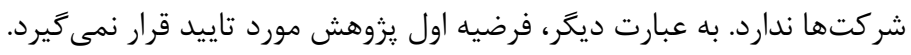

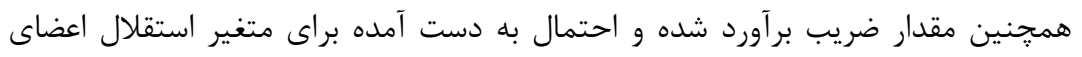

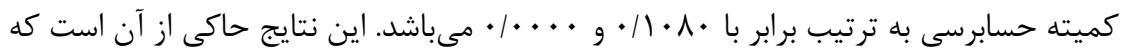

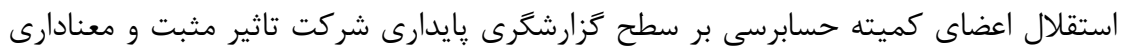

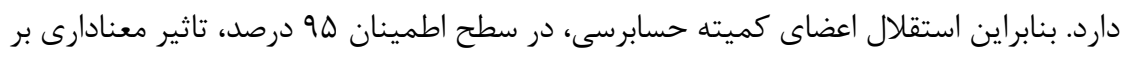

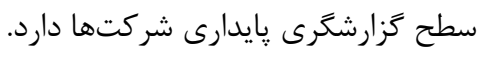

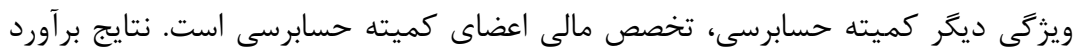

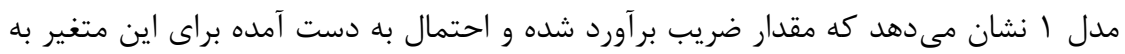

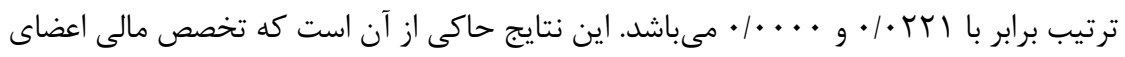

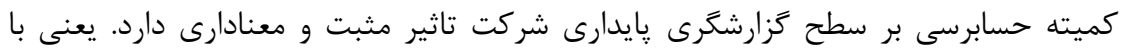

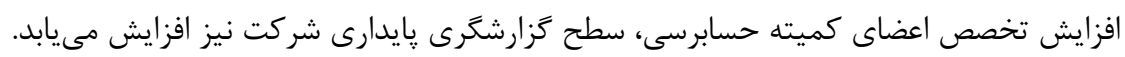

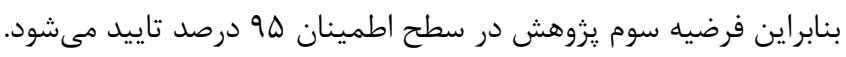

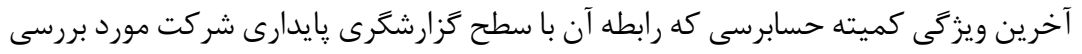

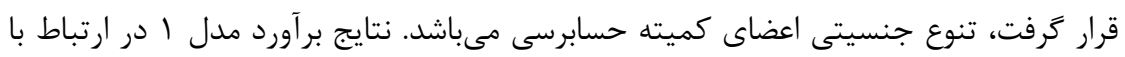

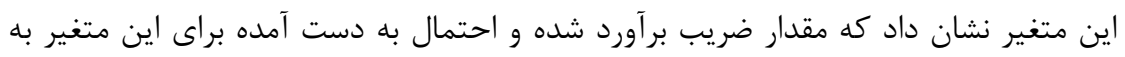

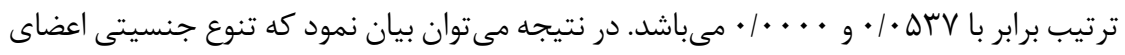

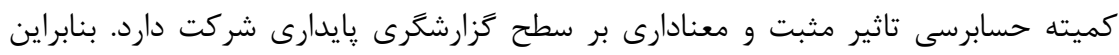

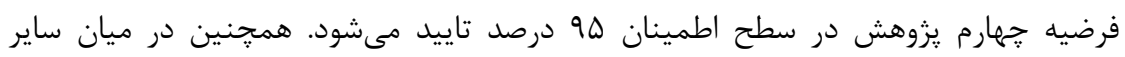

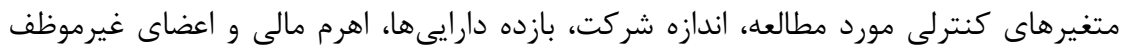

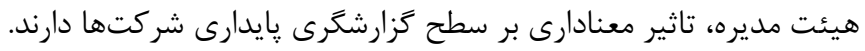




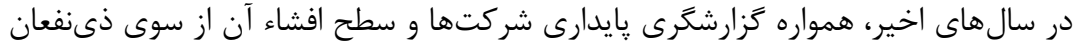

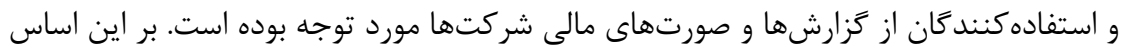

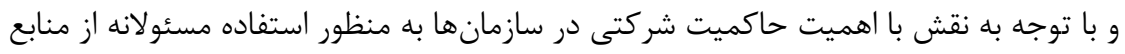

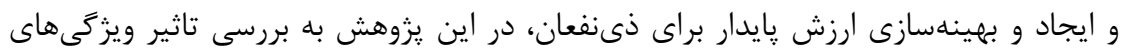

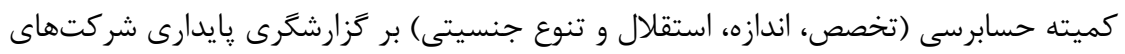
يذيرفته شده در بورس اوراق بهادار با تاكيد بر نظريه نمايندكى، نظريه مشروعيت و نظريه

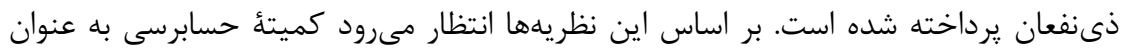

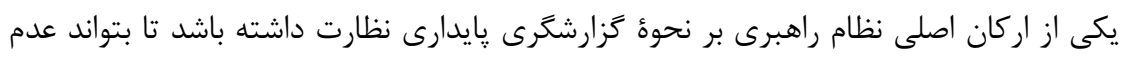

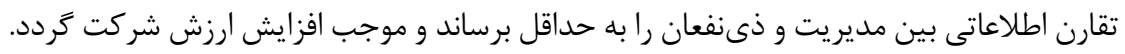

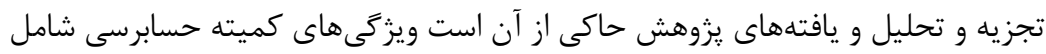

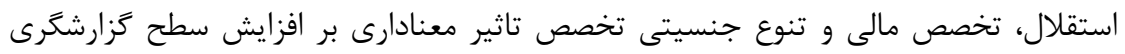

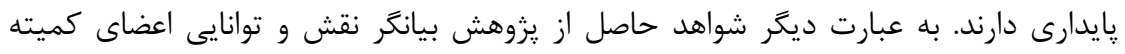

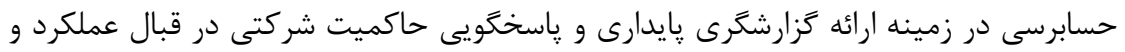

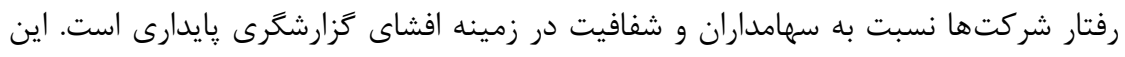

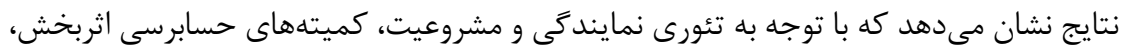

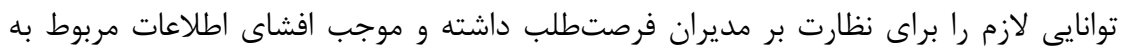

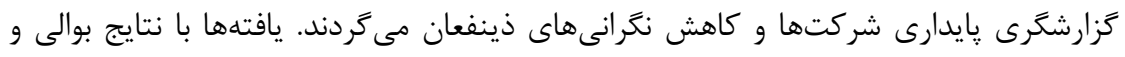

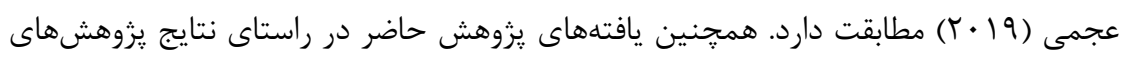

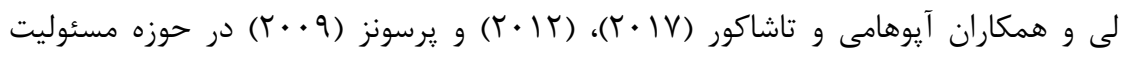

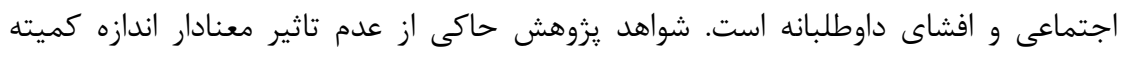

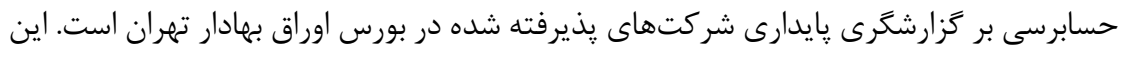

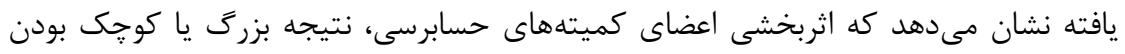

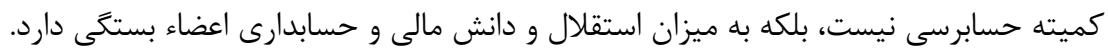

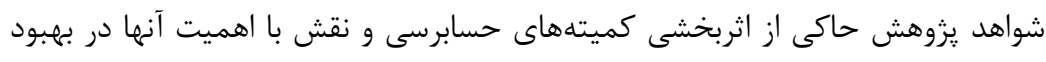

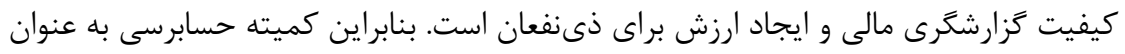

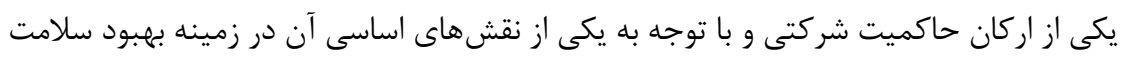

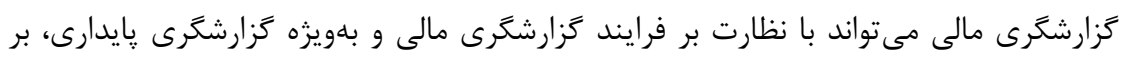
ارتقاى سطح و كيفيت آن بيافزايد. 


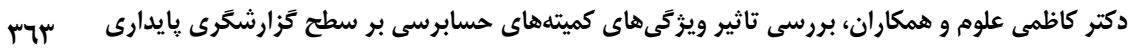

يافتههاى يزوهش مى تواند مورد استفاده سهامداران و ذينفعان و همجنين نهادهاى ذىربط و و تدوين كنند

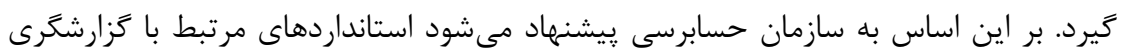

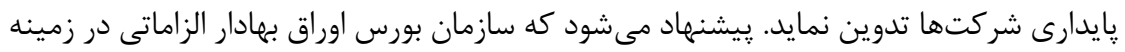

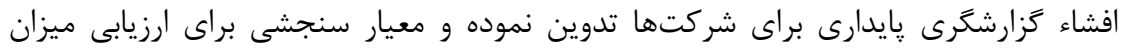

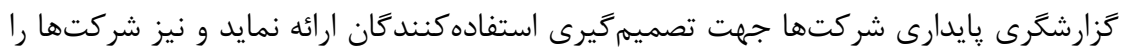
به سمت استقرار كميته هاى مستقل كزارشكرى بايدارى در اركان حاكميت شركتى آنها آنها هدايت

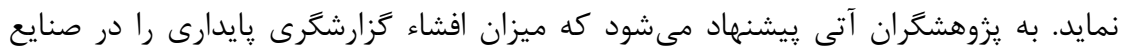

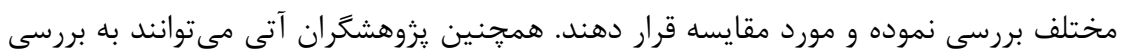

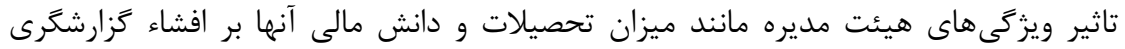

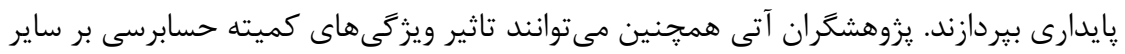

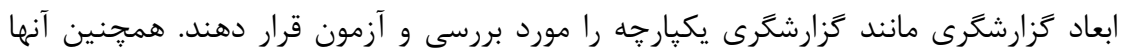

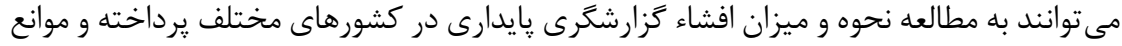

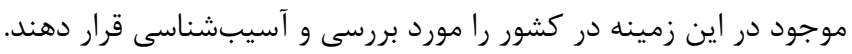

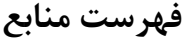

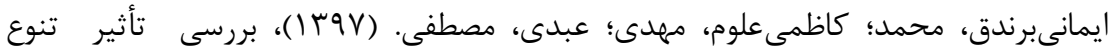

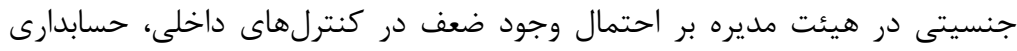

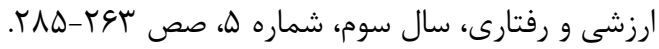

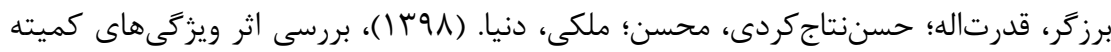

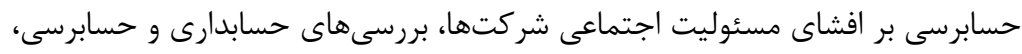

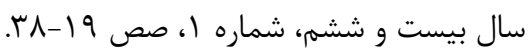

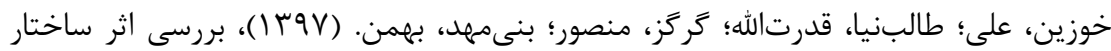

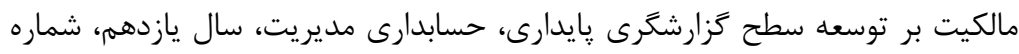

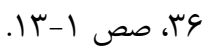

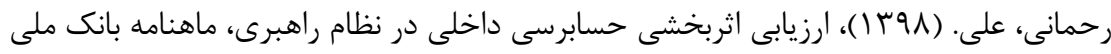

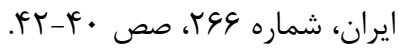

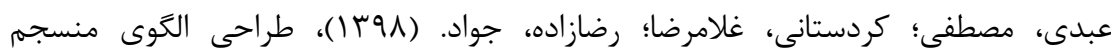

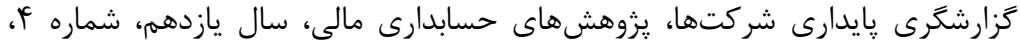

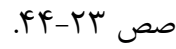




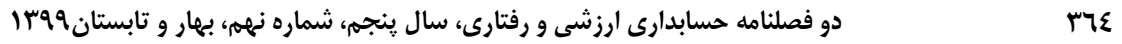

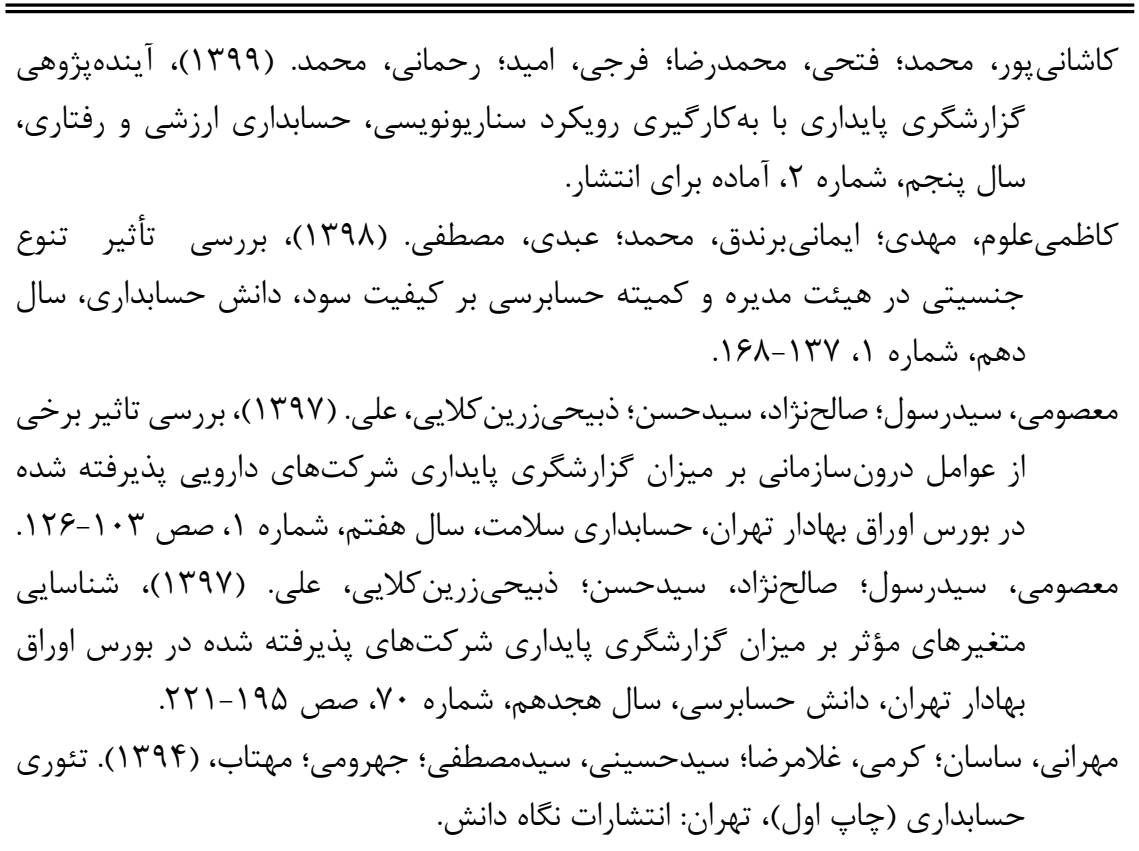

Abbott, L., J. Y. Park, and S. Parker. 2000. The effects of audit committee activity and independence on corporate fraud. Managerial Finance 26 (11): 55-68.

Adams, R., J. de Haan., S. Terjesen, and H. van Ees. 2015. Board diversity: moving the field forward. Corporate Governance: An International Review 23 (2): 77-82.

Ajinkya, B., S. Bhojraj and P. Sengupta. 2005. The Association Between Outside Directors, Institutional Investors and the Properties of Management Earning Forecast. Journal of Accounting Research 43 (3): 343-376.

Alderman, H., K. Duncan., S. Kelly and R. McNamara. 2011. Performance of family firms during the global financial crisis: does governance matter?, paper presented in 3rd Conference on Financial Markets and Corporate Governance La Trobe University, Melbourne.

Allegrini, M. and G Greco. 2013. Corporate boards, audit committees and voluntary disclosure: evidence from Italian listed companies. Journal of Management \& Governance 17(1): 187-216.

Al-Shaer, H. and M. Zaman. 2016. Board Gender Diversity and Sustainability Reporting Quality. Journal of Contemporary Accounting \& Economics 12: $210-222$. 


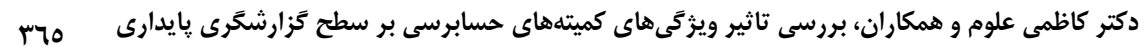

Appuhami, R. and S Tashakor. 2017. The Impact of Audit Committee Disclosure: An analysis of Australian Firms. Australian Accounting Review 27 (4): 400-420.

Badolato, P.G., D.C. Donelson and M. Ege. 2014. Audit committee financial expertise and earnings management: the role of status. Journal of Accounting and Economics 58 (2): 208-230.

Barako, D.G., P. Hancock and H.Y. Izan. 2006. Factors influencing voluntary corporate disclosure by Kenyan companies. Corporate Governance: An International Review 14 (2): 107-125.

Baxter, P. and J. Cotter. 2009. Audit committees and earnings quality. Accounting \& Finance 49 (2): 267-290.

Bedard, J. and Y. Gendron. 2010. Strengthening the financial reporting system: can audit committees deliver?. International Journal of Auditing 14(2): 174-210.

Bernardi, R.A., D.F. Bean and K.M. Weippert. 2002. Signaling Gender Diversity through Annual Report Pictures: A Research Note on Image Management. Accounting, Auditing \& Accountability Journal 15(4): 609- 616.

Buallay, A., and J. Al-Ajmi. 2019. The role of audit committee attributes in corporate sustainability reporting: Evidence from banks in the Gulf Cooperation Council. Journal of Applied Accounting Research, 1-17.

Castelo Branco, M. and L. Lima Rodrigues. 2006. Communication of corporate social responsibility by Portuguese banks: a legitimacy theory perspective. Corporate Communications: An International Journal 11 (3): 232-248.

Chen, Y., J. Eshleman and J. Soileau. 2016. Board Gender Diversity and Internal Control Weaknesses. Advances in Accounting 32 (1):65-90.

Clarkson, P.M., Y. Li., G.D. Richardson and F.P. Vasvari. 2008. Revisiting the relation between environmental performance and environmental disclosure: an empirical analysis. Accounting, Organizations and Society 33(4): 303-327.

Clarkson, P. M., Y. Li, G.D. Richardson and F.P. Vasvari. 2011. Does it Really Pay to Be Green? Determinants and Consequences of Proactive Environmental Strategies. Journal of Accounting and Public Policy 30 (2): 122-144.

Crifo, P., E.Escrig - Olmedo, and N.Mottis. 2018. Corporate Governance as a Key Driver of Corporate Sustainability in France: The Role of Board Members and Investor Relations. Journal of Business Ethics.

Daily, C. M., S. T Certo and D. R. Dalton. 2000. Research notes and communications: International experience in the executive suite: the path to prosperity. Strategic Management Journal 21: 515-523. 
Fama, E.F. and M. C. Jensen. 1983. Separation of ownership and control. The Journal of Law and Economics 26(2): 301-325.

Fatemi, A., M. Glaum and S. Kaiser. 2018. ESG performance and firm value: the moderating role of disclosure. Global Finance Journal 38: 45-64.

Frankel, R., S. McVay and M. Soliman. 2011. Non-GAAP earnings and board independence. Review of Accounting Studies 16 (4): 719-744.

Freeman, R. E. 1984. Strategic Management: A Stakeholder Perspective. Boston: Pitman Publishing. Governance. Accounting \& Finance 50 (1): 171-195.

Gray, R., K. Kouhy and S. Lavers. 2008. Corporate social and environmental reporting: a review of the literature and a longitudinal study of UK disclosures accounting. Auditing and Accountability Journal 8 (2): 47 77.

Harjoto, M., I. Laksmana and R. Lee. 2014. Board diversity and corporate social responsibility. Journal of Business Ethics 1-20.

Herzig, C., T. Viere., R. Burritt and S. Schaltegger. 2006. Understanding and supporting management decision-making. South East Asian case studies on environmental management accounting. Stainability Accounting and Reporting, Springer, Dordrecht 491-507.

Hoitash, U., R. Hoitash and J.C. Bedard. 2009. Corporate governance and internal control over financial reporting: a comparison of regulatory regimes. The Accounting Review 84 (3): 839-867.

Isidro, H., and M. Sobral. 2014. The effects of women on corporate boards on firm value, financial performance, and ethical and social compliance. Journal of Business Ethics 1-19.

Jensen, M. and W. Meckling. 1976. Theory of the firm: managerial behavior, agency costs and ownership structure. Journal of Financial Economics 3 (3): 305-360.

Jensen, M. 2001. Value Maximization, Stakeholder Theory, and the Corporate Objective Function. European Financial Management 7 (3): 297-317.

Jizi, M.I., A. Salama., R. Dixon and R. Stratling. 2014.Corporate governance and corporate social responsibility disclosure: evidence from the US banking sector. Journal of Business Ethics 125(\$): 601-615.

Karamanou, I. and N. Vafeas. 2005. The association between corporate boards, audit committees, and management earnings forecasts: an empirical analysis. Journal of Accounting Research 43(3): 453-486.

Kent, P., J. Routledge and J. Stewart. 2010. Innate and discretionary accruals quality and corporate governance. Accounting \& Finance 50 (1): 171195.

Kiron, D., N. Kruschwitz., K. Haanaes., M. Reeves., S. FuiszKehrbach and G. Kell. 2015. Joining Forces: Collaboration and Leadership for 


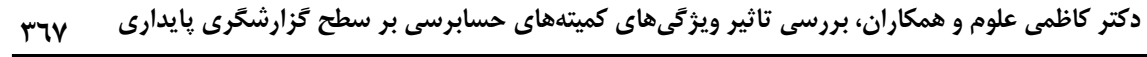

Sustainability. MIT Sloan Management Review, the Boston Consulting Group, and the United Nations Global Compact. http://marketing.mitsmr.com/PDF/56380-MITSMR-BGC-

UNGCSustainability2015.pdf?cid=1 (accessed January 12).

Kuzey, C., Uyar, A. (2017). Determinants of sustainability reporting and its impact on firm value: evidence from the emerging market of Turkey. Journal of Cleaner Production, 143, 27-39.

KPMG. 2011. KPMG international survey of corporate social responsibility reporting 2011. www.kpmg.de/docs/survey-corporate-responsibilityreporting-2011.pdf

Krishnan, G.V. and G. Visvanathan. 2007. Reporting internal control deficiencies in the post- Sarbanes-Oxley era: the role of auditors and corporate governance. International Journal of Auditing 11 (2): 73-90.

Laplume, A.O., K. Sonpar and R.A. Litz. 2008. Stakeholder theory: reviewing a theory that moves us. Journal of Management 34 (6): 11521189.

Leftwich, R.W., R.L. Watts and J.L. Zimmerman. 1981. Voluntary corporate disclosure: the case of interim reporting. Journal of Accounting Research 18 (1): 50-77.

Li, J., M. Mangena and R. Pike. 2012. The effect of audit committee characteristics on intellectual capital disclosure. The British Accounting Review 44 (2): 98-110.

Madi, H.K., Z. Ishak and N.A.A $>$ Manaf. 2014. The impact of audit committee characteristics on corporate voluntary disclosure.ProcediaSocial and Behavioral Sciences 164: 486-492.

Mangena, M. and V. Tauringana. 2007. Corporate compliance with nonmandatory statements of best practice: the case of the ASB statement on interim reports. European Accounting Review 16 (2): 399-427.

Mangena, M., and R. Pike. 2005. The Effect of Audit Committee Shareholding, Financial Expertise and Size on Interim Financial Disclosures. Accounting \& Business Research, 35 (4): 327-349.

Mistry, V., U. Sharma and M. Low. 2014. Management accountants' perception of their role in accounting for sustainable development: an exploratory study. Pacific Accounting Review 26 (1): 112-133.

Naciti, V. 2019. Corporate governance and board of directors: the effect of a board composition on firm sustainability performance. Journal of Cleaner Production, 237, 1-18.

Neifar, S. and A. Jarboui. 2018. Corporate governance and operational risk voluntary disclosure: evidence from Islamic banks", Research in International Business and Finance 46 (1): 43-54. 
Persons, O.S. 2009. Audit committee characteristics and earlier voluntary ethics disclosure among fraud and no-fraud firms. International Journal of Disclosure and Governance 6 (4): 284-297.

Petra, S. T. 2005. Do outside independent directors strengthen corporate boards? Corporate Governance: The international journal of business in society 5 (1): 55-64.

Pucheta-Martınez, M.C., and C. De Fuentes. 2007. The Impact of Audit Committee Characteristics on the Enhancement of the Quality of Financial Reporting: An Empirical Study in the Spanish Context. Corporate Governance: An International Review 15 (6): 1394-1412.

Rao, K. and C. Tilt. 2016. Board diversity and CSR reporting: an Australian study. Meditari Accountancy Research 24 (2): 182-210.

Ray, S., B. Ray Chaudhuri. 2018. Business group affiliation and corporate sustainability strategies of firms: an investigation of firms in India. Journal of Business Ethics 153 (4): 955-976.

Rezaee, Z. 2016. Business Sustainability Research: A Theoretical and Integrated Perspective. Journal of Accounting Literature 36: 48-64.

Rezaee, Z. 2017. Corporate Sustainability: Theoretical and Integrated Strategic Imperative and Pragmatic Approach. The Journal of Business Inquiry 16: 60-87.

Samaha, K., H. Khlif and K. Hussainey. 2015. The impact of board and audit committee characteristics on voluntary disclosure: a meta-analysis. Journal of International Accounting, Auditing and Taxation 24 (1): 1328.

Sharma, U. and M. Kelly. 2014. Students' perceptions of education for sustainable development in the accounting and business curriculum at a business school in New Zealand. Meditari Accountancy Research 22 (2): 130-148.

Sultana, N., M. Van der and J.L. Zahn. 2015. Earnings conservatism and audit committee financial expertise. Accounting \& Finance 55 (1): 279-310.

Tilling, M. V. 2004. Some Thoughts on Legitimacy Theory in Social and Environmental Accounting. Social and Environmental Accountability Journal 24 (2): 3-7.

Vafeas, N. 2005. Audit committees, boards, and the quality of reported earnings. Contemporary Accounting Research 22 (4): 1093-1122.

Waddock, S.A. and S.B. Graves. 1997. The corporate social performancefinancial performance link .Strategic Management Journal 18 (4): 303319.

Weber, M. 2008. The Business Case for Corporate Social Responsibility: A Company- Level Measurement Approach for CSR. European Management Journal 26 (4): 247-61. 
دكتر كاظمى علوم و همكاران، بررسى تاثير ويزَّىهاى كميتههاى حسابرسى بر سطح كَزارشَّى هايدارى 97س

Wijen, F. 2014. Means Versus Ends in Opaque Institutional Fields: Trading off Compliance and Achievement in Sustainability Standards Adoption. Academy of Management Review 39 (3): 302-323.

Wilburn, K. and R.Wilburn. 2013. Using global reporting initiative indicators for CSR programs. Journal of Global Responsibility 4 (1): 62-75.

Woidtke, T. and Y.H. Yeh. 2013. The role of the audit committee and the informativeness of accounting earnings in East Asia. Pacific-Basin Finance Journal 23 (1): 1-24.

Yuen, C.Y, M. Liu., X. Zhang and C. Lu. 2009. A Case Study of Voluntary Disclosure by Chinese Enterprises. Asian Journal of Finance \& Accounting. 1(2): 118-145.

Zhang, J. Q. , H. Zhu and H. B. Ding. 2013. Board composition and corporate social responsibility: An empirical investigation in the post SarbanesOxley era. Journal of Business Ethics 114 (3): 381-392.

Zou,Z., Y. Wu., Q. Zhu and SH. Yang. 2018.. Do Female Executives Prioritize Corporate Social Responsibility? Emerging Markets Finance and Trade 2965-2981. 